\title{
On the origin of Goa Cathedral former altarpiece: Material and technical assessment to the work of Garcia Fernandes, Portuguese painter from 16th century Lisbon workshop
}

\author{
Vanessa Antunes a,b,*, António Candeias c,d , José Mirão d, Maria L. Carvalho a , Vitor Serrão ${ }^{\text {b }}$, \\ Cristina Barrocas Dias ${ }^{\mathrm{d}}$, Ana Manhita ${ }^{\mathrm{d}}$, Ana Cardoso ${ }^{\mathrm{d}}$, Marta Manso ${ }^{\mathrm{a}, \mathrm{e}}$

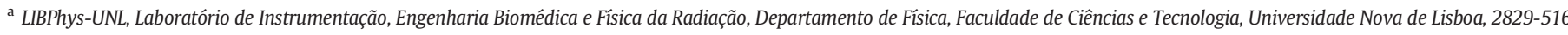 \\ Caparica, Portugal \\ b ARTIS-IHA- Instituto História da Arte, Faculdade de Letras, Universidade de Lisboa (ARTIS-IHA, FLUL), Alameda da Universidade, 1600-214 Lisboa, Portugal \\ c Laboratório José de Figueiredo, Direcção-Geral do Património Cultural (LJF-DGPC), Rua das Janelas Verdes 37, $1249-018$ Lisboa, Portugal \\ d Laboratório HERCULES, Escola de Ciências e Tecnologia, Universidade de Évora, Largo Marquês de Marialva 8, 7000-676 Évora, Portugal \\ e Faculdade de Belas-Artes, Universidade de Lisboa, Largo da Academia Nacional de Belas-Artes, 1249-058 Lisboa, Portugal
}

\section{A R T I C L E I N F O}

\section{Article history:}

Received 31 August 2017

Received in revised form 16 December 2017

Accepted 12 January 2018

Available online 16 January 2018

\section{Keywords:}

Portuguese painting

Ground layer

Gypsum

Anhydrite

Pigments

Garcia Fernandes

\begin{abstract}
A B S T R A C T
Goa Cathedral former altarpiece is one of the oldest set of paintings in India. The seven remaining paintings from the first altarpiece of Goa Cathedral, nowadays in the sacristy, are attributed by some art historians to Master Garcia Fernandes (act. 1514-1565), Portuguese painter from Lisbon workshop. The 16th century was the "Golden age" of Portuguese painting. In this context the Royal Lisbon workshop played a predominant role, where the activity of the painter Garcia Fernandes and his workshop can be distinguished. In this new approach, Goa paintings are being studied and compared with other works in Portuguese territory attributed to this same painter, as St. Bartholomew altarpiece from the chapel of Bartolomeu Joanes in Lisbon Cathedral.

The stratigraphic study allowed to compare ground layers, pigments and binders which, were characterized using complementary analytical and imaging techniques: (X-ray Fluorescence spectrometry (XRF), Infrared Reflectography (IRR), Infrared Photography (IRP), Macro Photography (MP), micro-X-ray Diffraction ( $\mu$-XRD), Scanning Electron Microscopy with Energy Dispersive Spectroscopy (SEM-EDS), Raman micro-spectroscopy ( $\mu$-Raman), Fourier Transform Infrared micro-spectroscopy ( $\mu$-FTIR), Pyrolysis gas chromatography mass spectrometry (PY-GC/MS). This work brought a new insight on the techniques and materials used in this Masterpiece and highlighted the conclusion that Goa Cathedral former altarpiece must be a Portuguese production.
\end{abstract}

(c) 2018 Elsevier B.V. All rights reserved.

\section{Introduction-pictorial corpus under study}

Garcia Fernandes was apprentice in the workshop of his uncle Jorge Afonso, the main chief of Lisbon workshop and he was already considered a great painter at his time. His work is recognized by some art historians in the paintings that constituted the first main altarpiece devoted to Saint Catherine, made circa 1530 for the Goa Cathedral. This Cathedral was built after a promise of the Viceroy of Portuguese India, Afonso de Albuquerque, in 1510, being one of the oldest and largest cathedrals in Asia [1-8]. This episode occurred on Saint Catherine's day, marking the capture of the city of Goa by the Portuguese.

\footnotetext{
* Corresponding author at: LIBPhys-UNL, Laboratório de Instrumentação, Engenharia Biomédica e Física da Radiação, Departamento de Física, Faculdade de Ciências e Tecnologia, Universidade Nova de Lisboa, 2829-516 Caparica, Portugal.

E-mail address: vanessahantunes@gmail.com (V. Antunes).
}

Goa Cathedral painted altarpiece was kept as the main altar in the church until the 17th century, being replaced at that time by a gold leaf carved altarpiece [9]. Nowadays, the former altarpiece is kept in the sacristy. Although, the iconographic and artistic importance of this altarpiece were considered by the next generation of Goan artists. The artists that made the gold leaf carved altarpiece respected the themes and iconography painted in the first Goa Cathedral altarpiece [9]. The themes represented in this altarpiece are Saint Catherine of Alexandria with martyr's palm (P1), the Assumption of St. Catherine of Alexandria (P2), the beheading of St. Catherine of Alexandria (P3), St. Catherine survival of death by a spiked wheel (P4), St. Catherine imprisonment by the Emperor (P5), the debate with pagan scholars and The Empress's visit and conversion. One of the most important of this set of seven paintings is Saint Catherine of Alexandria with martyr's palm (P1) since it represents the triumph of the martyr Saint Catherine over the pagan emperor (Fig. 1), being at the same time one of the paintings in worst state of conservation. 
a)

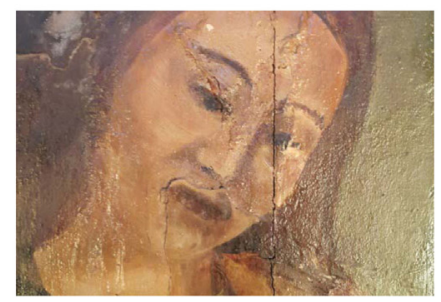

b)

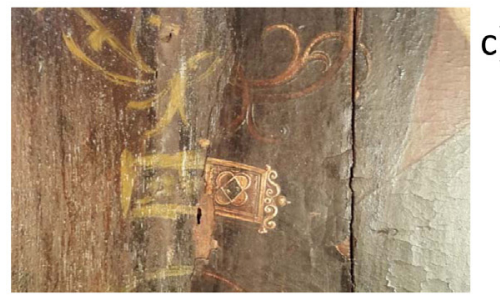

c)

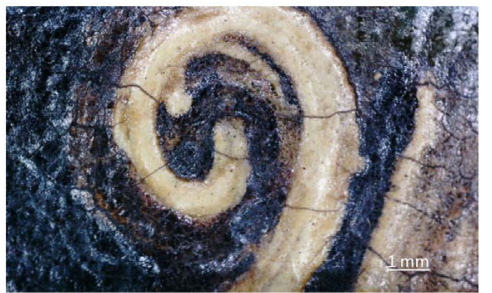

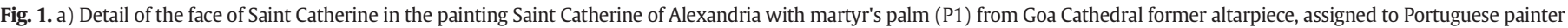

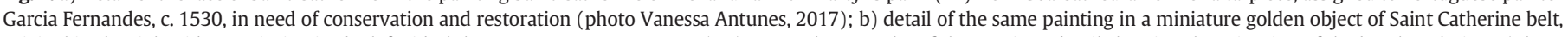

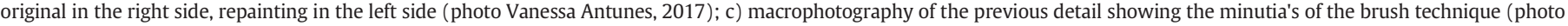
Vanessa Antunes, 2017).

Garcia Fernandes collaborated with his father-in-law, the Flemish painter Francisco Henriques, having succeeded him in the post of headmaster of his workshop after the Master's death in 1518. He also worked in partnership (1533-34) with other renowned painters in Portuguese panorama, such as Cristóvão de Utreque and the two painters Gregório Lopes and Cristóvão de Figueiredo, thus being integrated in the circle of the masters of Ferreirim. He worked in several convents and churches having his work distributed in several Portuguese regions, such as the case of the panel of Our Lady of the Assumption(A2), church of Santa Maria of Sardoura, Castelo de Paiva, c. 1530 [5, 10] and Lisbon Cathedral St. Bartholomew's altarpiece on the chapel of Bartolomeu Joanes (A3), dating from 1537, a possible partnership between Garcia Fernandes, Cristóvão de Figueiredo and Diogo de Contreiras and probably with the assistance of other collaborators, all 16th century Portuguese Great Masters [11, 12].

A group of four paintings from about $1535-1540$ is also assigned to this painter: Preaching of St. Anthony to the fishes (inv.1768 MNAA), Annunciation (inv. 1769 Pint MNAA), Pentecost (inv 1770 Pint Museu Nacional de Arte Antiga (MNAA)), and Testimony of St. John the Baptist with the priests and Levites of Jerusalem (A4) (inv. 1771Pint, MNAA) (A4), being this last one studied in terms of the technique and materials used for its making $[13,14]$.

This painter stands out from its coeval Portuguese artists not only for his highlighted pictorial technique but also as one of the few painters to be known for having produced works to India, as confirmed by his own testimony in 1540 during his petition to the Crown, reporting on several works made by him, which included working for India [14-16].

The importance of this painter in Portuguese panorama lead to different analytical studies on some works assigned to him. These previous studies were made by micro-X-ray diffraction ( $\mu$-XRD) and Fourier Transform Infrared micro-spectroscopy ( $\mu$-FTIR). This is the case of the painting Our Lady of the Assumption (A2) [15-17], of Lisbon Cathedral altarpiece of the chapel of Bartolomeu Joanes (A3) [18-20], and of the painting Testimony of Saint John the Baptist with the priests and Levites of Jerusalem (A4) [13, 21-23]. These studies can be compared to the results of Goa Cathedral former altarpiece (A1).

Other studies were made on the paintings of Gregório Lopes and Cristóvão de Figueiredo and the pigments used: lamp black, lead white, azurite, goethite, lead-tin yellow type I, red lead, hematite, vermilion, as well red madder dye and indigo were similar to those used by Garcia Fernandes in his works. Calcium carbonate grains were found as fillers in certain colors, such as the Virgin's mantle blue. Ground layers had a mixture of gypsum and chalk $[24,25]$.

The study of Goa Cathedral former altarpiece (A1) aimed to compare the materials and techniques with the previous studied works of Garcia Fernandes workshop, bringing novelties and answering the question: can it be a Portuguese work? With the use of non-invasive techniques, of major importance for the preservation of cultural heritage, energy dispersive X ray fluorescence (EDXRF), infrared reflectography (IRR) and macro photography (MP) it was possible to identify the key-elements of the pigments, underdrawing and the overlapping technique of several painting layers for each color, respectively. Other complementary techniques were used by sampling the painting Saint Catherine of Alexandria with martyr's palm (P1) when it was necessary to further understand the involved pigments, and identify the artist's palette, and identify the specific type of ground layer, to compare it with the characteristic ground layers of Lisbon workshop; $\mu$-Raman to identify crystalline and amorphous compounds; $\mu$-X ray Diffraction ( $\mu$ XRD) allowed to confirm the previous technique in the identification of the ground layer phases, complemented with the morphological characterization and elemental distribution maps brought by SEMEDS; micro Fourier Transform Infrared ( $\mu$-FTIR) and pyrolysis gas chromatography mass spectrometry (PY-GC/MS) were used to analyze the organic binders in ground and painting layers [26]. The obtained results will be compared to ground layers and pigments composition of the previous studies of Garcia Fernandes.

\section{Material and methods}

\subsection{Sample collection and preparation}

Samples were collected and parts of them were embedded in an Epofix resin with hardener. Micro-mesh abrasive cloths with sequentially finer grades were used to dry polish the samples.

\subsection{Description of the analytical techniques}

\subsubsection{Infrared Reflectography (IRR), infrared photography (IRP), macro photography (MP)}

Examination by IR photography, raking light and UV light was carried out with a digital camera (SONYDSC-F828), 7 Mega Pixels, to photograph and register.

Macro-photographs of the chromatic layers were captured with a mobile microscope 3 "LCD 8.5 Mega Pixels 20-500×, Digital LCD with VGA, Micro SD card storage and a Micro Capture Pro software.

Infrared reflectography was performed with a high resolution infrared reflectography camera (Osiris) with an InGaAs detector allowing a wavelength response from 900 to $1700 \mathrm{~nm}$, and equipped with a $16 \times$ 16 tile system which enables an image size of $4096 \times 4096$ pixels. The camera is equipped with a long-pass filter Schott RG850, allowing to transmit infrared wavelength and block the undesired shorter wavelength until $850 \mathrm{~nm}$. Reflectograms were recorded with a working distance (front of body camera to painting) of $125 \mathrm{~cm}$, and focus (front of body camera to lens) of $28 \mathrm{~cm}$, an $\mathrm{f} / 11$ aperture and diffuse illumination at $1000 \mathrm{~lx}$ by reflectors with $2 \times 1000$ W Tungsten Halogen VC $-1000 \mathrm{Q}$ Quartz Light. The final image, composed by several reflectograms, was ensemble in Photoshop CS5, with the Photomerge tool. All the images had a small treatment, adjusting levels and increase contrast. The reflectograms were performed for $60 \times 60 \mathrm{~cm}^{2}$ of painting area [27].

\subsubsection{Portable energy dispersive X-ray fluorescence spectroscopy (EDXRF)}

Portable EDXRF technique was initially used to provide significant data on the painting materials. The determination of pigments elemental composition and trace elements was achieved with an XRF portable 
setup that consists of an Amptek Mini-X Rh X-ray generator ( $50 \mathrm{kV}, 200$ $\mu A$ max.) and an Amptek XR-100CR silicon PIN detector with a $7 \mathrm{~mm}^{2}$ detection area and $300 \mu \mathrm{m}$ thickness and a $12.5 \mu \mathrm{m}$ Be window. The angle between the incident and the emitted beam is $90^{\circ}$. This geometry allows for a high background reduction due to Compton scattering [28]. The energy resolution is $190 \mathrm{eV}$ at $5.9 \mathrm{keV}$ [29]. Analysis were carried out in air and the X-ray generator was operated at $30 \mathrm{kV}$ and $15 \mu \mathrm{A}$ during 120 s. Spectra were acquired using Pocket MCA software and its deconvolution and evaluation was performed using WinAXIL ${ }^{\circledR}$ software package by Canberra.

\subsubsection{Optical microscopy (OM)}

A Leica DM 2500 M optical dark field microscope coupled to a digital camera Leica MC170HD was used to study the cross-sections of each sample by optical microscopy (OM). Images were taken at different magnifications, from $100 \times$ to $500 \times$.

\subsubsection{Scanning electron microscopy with energy dispersive X-ray spec- trometry (SEM-EDS)}

SEM-EDS provides elemental distribution maps and morphological characterization and of the painting layers and ground layers. To perform elemental composition of the cross-sections by scanning electron microscopy imaging (Backscattering mode) a variable pressure Scanning Electron Microscopy with Energy Dispersive X-ray Spectroscopy (SEM-EDS) Hitachi S-3700N scanning electron microscope with a coupled Bruker XFlash 5010 SDD energy dispersive detector were used. The operating conditions for EDS analysis were $20 \mathrm{kV}$ accelerating voltage and $10-12 \mathrm{~mm}$ working distance. Samples were analyzed in variable pressure mode at 40 Pa without carbon coating to be further analyzed by other analytical methods [30].

\subsubsection{Micro - X-ray diffraction ( $\mu$-XRD)}

Micro-X-ray Diffraction was performed on samples of ground layers. They were analyzed unmounted to confirm its crystalline compounds. A Bruker AXS, D8 Discover microdiffraction system prepared with a onedimensional Lynx eye detector, a Goebel mirror, a laser-video sample alignment system and a motorized XYZ stage was used. Diffraction data were registered using $\mathrm{Cu} K \alpha$ radiation, tube running at $40 \mathrm{kV}, 40$ $\mathrm{mA}$, with the incident beam collimated to $1 \mathrm{~mm}$ diameter. XRD patterns were measured in the range $5^{\circ}$ to $75^{\circ} 2 \theta$, a step size of $0.05^{\circ}$, with a recording time of 1800 s for each step. For the identification of crystalline phases the Bruker EVA software with International Centre for Diffraction Data Powder Diffraction Files (ICDD PDF) was used [31].

\subsubsection{Micro-confocal Raman spectroscopy ( $\mu$-Raman)}

Raman analyses were undertaken using a Horiba-Jobin Yvon XploRA confocal spectrometer. Using a $785 \mathrm{~nm}$ excitation wavelength with a $100 \times$ magnification objective with a pinhole of $300 \mu \mathrm{m}$ and an entrance slit of $100 \mu \mathrm{m}$, the scattered light collected by the objective was dispersed onto the air-cooled CCD array of an Andor iDus detector by a 1200 lines/mm grating. The $100 \times$ objective was used in combination with a $1 \%$ filter rendering an incident power on the sample up to 0.20 $\pm 0.02 \mathrm{~mW}$ (lasercheck®, Edmund optics) Spectra deconvolution was performed using LabSpec (V5.78). The classification of pigments was made with Spectral ID ${ }^{\mathrm{TM}}$ and other databases [32-34]. Raman spectroscopy was performed in a range of $100-3000 \mathrm{~cm}^{-1}$ [35].

\subsubsection{Pyrolysis gas chromatography mass spectrometry (PY-GC/MS)}

A pyrolysis gas chromatography mass spectrometry (PY-GC/MS) system with a Pyrolyzer Frontier Lab PY-3030D double-shot was used for the analysis of organic binder in ground layers. A stereomicroscope was used to separate chromatic and ground layers for each sample $(<200 \mu \mathrm{g})$. The samples were previously derivatized in a $50 \mu \mathrm{L}$ Eco-cup capsule. Samples were placed in the double-shot pyrolizer and after a 2-minute helium purge. A single-shot method at $500{ }^{\circ} \mathrm{C}$ for $12 \mathrm{~s}$ was made to pyrolyze each sample and the interface was maintained at a temperature of $280{ }^{\circ} \mathrm{C}$. The pyrolizer was coupled to a Shimadzu GC2010 gas chromatographer and to a Shimadzu GCMS-QP2010 Plus mass spectrometer. A capillary column Phenomenex Zebron-ZB-5HT (30 m length, $0.25 \mathrm{~mm}$ internal diameter, $0.50 \mu \mathrm{m}$ film thickness) was used for separation, with helium as carrier gas, adjusted to a flow of $1.5 \mathrm{~mL} \mathrm{~min}^{-1}$. The splitless injector was operated at a temperature of $250{ }^{\circ} \mathrm{C}$. GC temperature programme was the following: $40{ }^{\circ} \mathrm{C}$ for 5 min, ramp until $300{ }^{\circ} \mathrm{C}$ at $5^{\circ} \mathrm{C} \mathrm{min}{ }^{-1}$, with an isothermal period of 3 min. Source temperature was placed at $240{ }^{\circ} \mathrm{C}$ and the interface temperature was maintained at $280{ }^{\circ} \mathrm{C}$. The mass spectrometer was programmed to acquire data between 40 and $850 \mathrm{~m} / \mathrm{z}$. Software AMDIS, according to NIST and Wiley databases were used to compound identification [27].

\subsubsection{Micro-Fourier transform infrared spectroscopy}

To confirm binders in ground layers, Fourier Transform Infrared spectroscopy ( $\mu$-FTIR) analysis was performed. A Bruker spectrometer Tensor 27 model at medium infrared region (MIR), in transmission mode, with a $15 \times$ objective and a diamond compression microcell EX'Press 1.6 mm, STJ-0169 were used. A microscope Hyperion 3000 controlled by software OPUS 7.2 from Bruker and a Mercury Cadmium Telluride detector are used in the spectrometer. For each spectrum a spectral resolution of $4 \mathrm{~cm}^{-1}$ in a working range of $4000-600 \mathrm{~cm}^{-1}$ and 64 scans were recorded [30].

\section{Results and discussion}

\subsection{Panel characteristics}

Each of the seven panels is composed of several boards placed vertically and joined with wooden dowels, which is common in Portuguese panel painting technique [36]. The supports are made of Baltic oak. This type of wood was not a local wood in Goa at the time [37]. Oak was imported to Portugal from Baltic to make the most important paintings, such as the paintings made upon real orders, being predominant in the Lisbon region [38], the working area of Garcia Fernandes. That is the case of the Lisbon Cathedral altarpiece of the chapel of Bartolomeu Joanes (A3) [20] and the painting Testimony of Saint John the Baptist with the priests and Levites of Jerusalem (A4). Its dendrochronological analysis indicates the date of probable starting of the painting from 1534 [21, 23]. Although, the painting Our Lady of the Assumption (A2), also assigned to Garcia Fernandes, is made on chestnut wood [17].

The dendrochronological study of Goa Cathedral former altarpiece (A1) is not possible before restoration due to the poor conditions of conservation of the panels. This environment is worth noting, since Goa climate is very different from Portuguese thermo-hygrometric conditions, increasing tremendously the degradation of the panels [26]. The painter could be aware of the results of the reaction of European materials in an Asian climate but decided to use this type of wood since it was considered the most noble and high quality wood used in the realm commissions.

\subsection{Ground layers}

The study of Goa Cathedral former altarpiece (A1) showed that the painting Saint Catherine of Alexandria with martyr's palm (P1) is made of a double-layered calcium sulfate ground, such as the previously studied paintings from Garcia Fernandes workshop [39]. Micro-XRD analysis shows a bigger percentage of anhydrite $\left(\mathrm{CaSO}_{4}\right)$ than gypsum $\left(\mathrm{CaSO}_{4} \cdot 2 \mathrm{H}_{2} \mathrm{O}\right)$ and only anhydrite in some cases of studied samples (Fig. 2a). Although, $\mu$-Raman analysis of the cross-sections puts in evidence the fact that gypsum (main peak at $1012 \mathrm{~cm}^{-1}$ ) is more frequent in the upper layer, being anhydrite (main peak at $1020 \mathrm{~cm}^{-1}$ ) more frequent in the first layer of the ground. This fact is corroborated by the morphologic analysis made by OM and SEM-EDS where it is possible 
a)

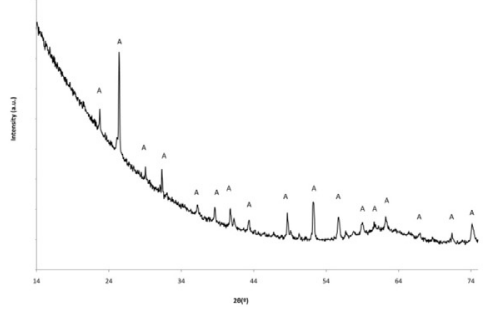

b)

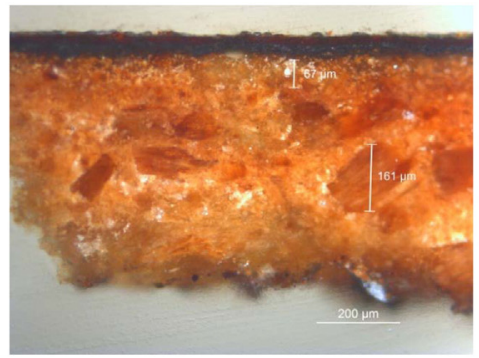

c)

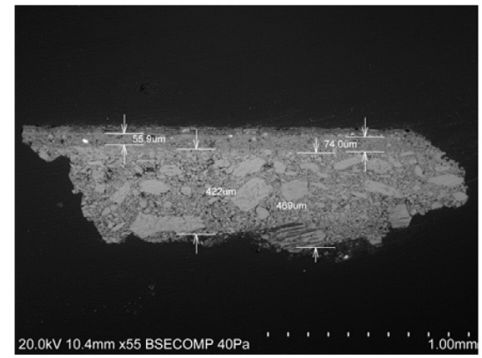

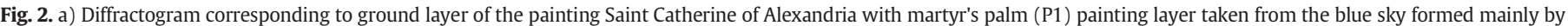

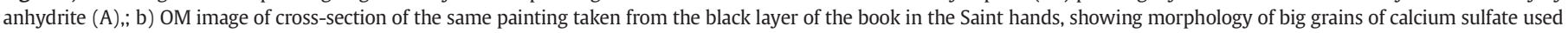

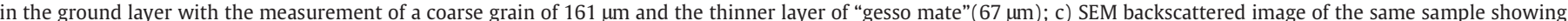

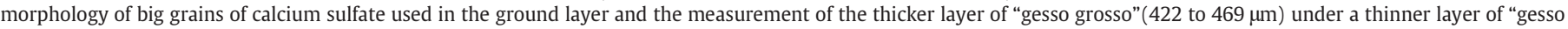
mate" (56 to $74 \mu \mathrm{m})$

to detect the thinner form of the gypsum grains in this upper layer, nearer to the painting surface (Figs. 2b, 2c and 3a). This type of ground layer (gesso grosso under gesso mate) is frequently found in gilded altarpieces [40]. After the employment of gesso grosso (coarse calcium sulfate, more anhydrite than gypsum) it was necessary the employment of gesso mate (thinner calcium sulfate, more gypsum than anhydrite) to smooth the surface to be gilded [40], as described in Portuguese treatises [41]. In the case of the paintings of Goa Cathedral former altarpiece (A1), although nowadays it presents no gold leaf, this technique was used probably to face the different thermo-hygrometric conditions of its transportation from Portugal and staying in Goa. This can be explained by the big anhydrite grains found in the first ground layer employed (Fig. 3a). These are coarser grains than the ones found in the other studied paintings from this workshop [39]. Coarse grains make the ground layer more resistant and flexible to thermo-hygrometric oscillations [39, 40]. SEM-EDS also has shown the occurrence of grains with $\mathrm{Sr}-\mathrm{Ba}$, indicating the presence of celestite $\left(\mathrm{SrSO}_{4}\right)$, often found in the previous paintings of this workshop and in ground layers of Portuguese painting (Figs. 3a and b) [42]. This occurrence may suggest a similar provenance of calcium sulfate raw material.

A few calcium grains were also found in the first gesso grosso layer of the ground. These grains suggest the presence of calcite. Unlike the calcite grains found in the other studied group of paintings (A3) from Garcia Fernandes workshop, these grains were not constituent of the upper thinly grinded layer of gesso mate. These results may suggest that the use of gypsum was enough to bring a desirable white color and smoothness to the layer that would receive the paint layers. In PY-GC/MS technique the only organic material identified in the ground layer was linseed oil, not being identified biomarkers for the presence of proteic binders. This is probably due to the fact that protein material had been used in small amounts, and/or due to the degradation of proteic materials, being these paintings are in bad state of conservation due to the adverse thermo-hygrometric climate [26]. During Py-GC/MS also, no biomarkers were detected for the use of gums or waxes as binders. In paint samples, the ratio between palmitic and stearic $(\mathrm{P} / \mathrm{S})$ acids can be used to distinguish between drying oils. Peak areas of palmitic acid (retention time $\sim 39.5 \mathrm{~min}$ ) and stearic acid (retention time $\sim 43.3$ $\mathrm{min}$ ) were considered for the calculations. The values for the $\mathrm{P} / \mathrm{S}$ ratios of the analyzed samples were $\leq 2$, suggesting the use of linseed oil (Fig. 4).

Although, $\mu$-FTIR identified the presence of oil and protein, probably animal glue, material stated by ancient Portuguese treatises for the making of calcium sulfate ground layers [41], along with other mineral compounds such as gypsum, anhydrite and silicates. FTIR spectra show that oil constituent is in preponderance regarding the protein element, given the comparative ease in identifying the oil in opposition to the protein [26]. The bands at 2931 and $2858 \mathrm{~cm}^{-1}$ correspond to an antisymmetric and symmetrical stretching, respectively, of $\mathrm{C}-\mathrm{H}$ bonds of alkyl groups, and the stretching band $\mathrm{C}=0$ at $1706 \mathrm{~cm}^{-1}$ indicate the presence of oil. The bands at 1457 and $1447 \mathrm{~cm}^{-1}$ of amide III are connected with the incidence of protein, in this case most likely animal glue.

Gypsum is shown with the 3483,3406 and $3246 \mathrm{~cm}^{-1}$ bands consequent to a $\mathrm{O}-\mathrm{H}$ stretching of the water molecules present in the gypsum structural system, the bands at 1685 and $1621 \mathrm{~cm}^{-1}$ ascribed to a bending of the $\mathrm{OH}$ group of the water molecules, the bands at 1132 and $1116 \mathrm{~cm}^{-1}$ correspondingly at antisymmetric stretching of the SO4 group. a)

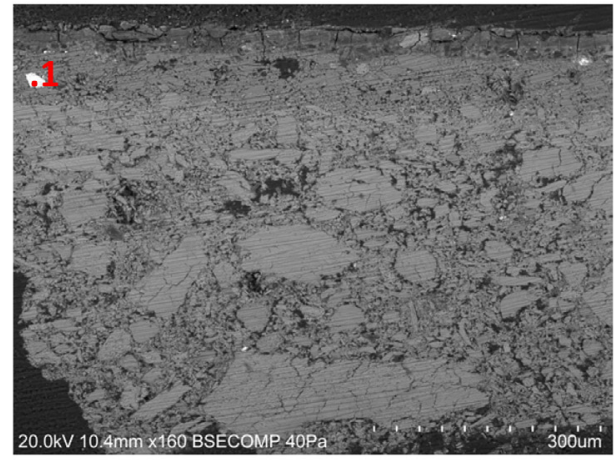

b)

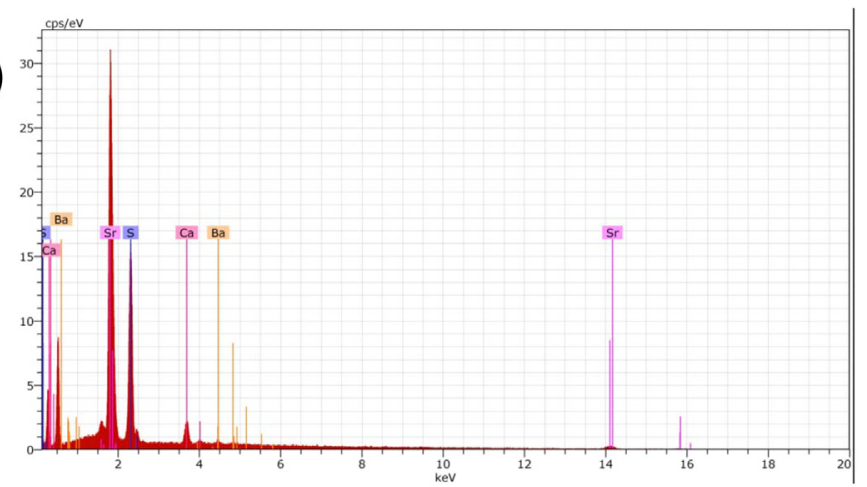

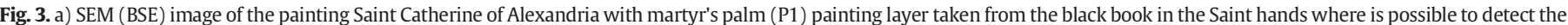

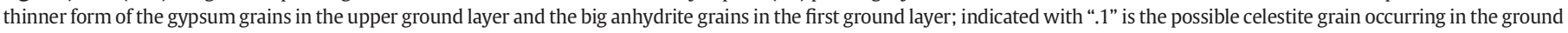

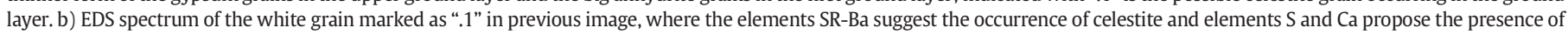
calcium sulfate. 


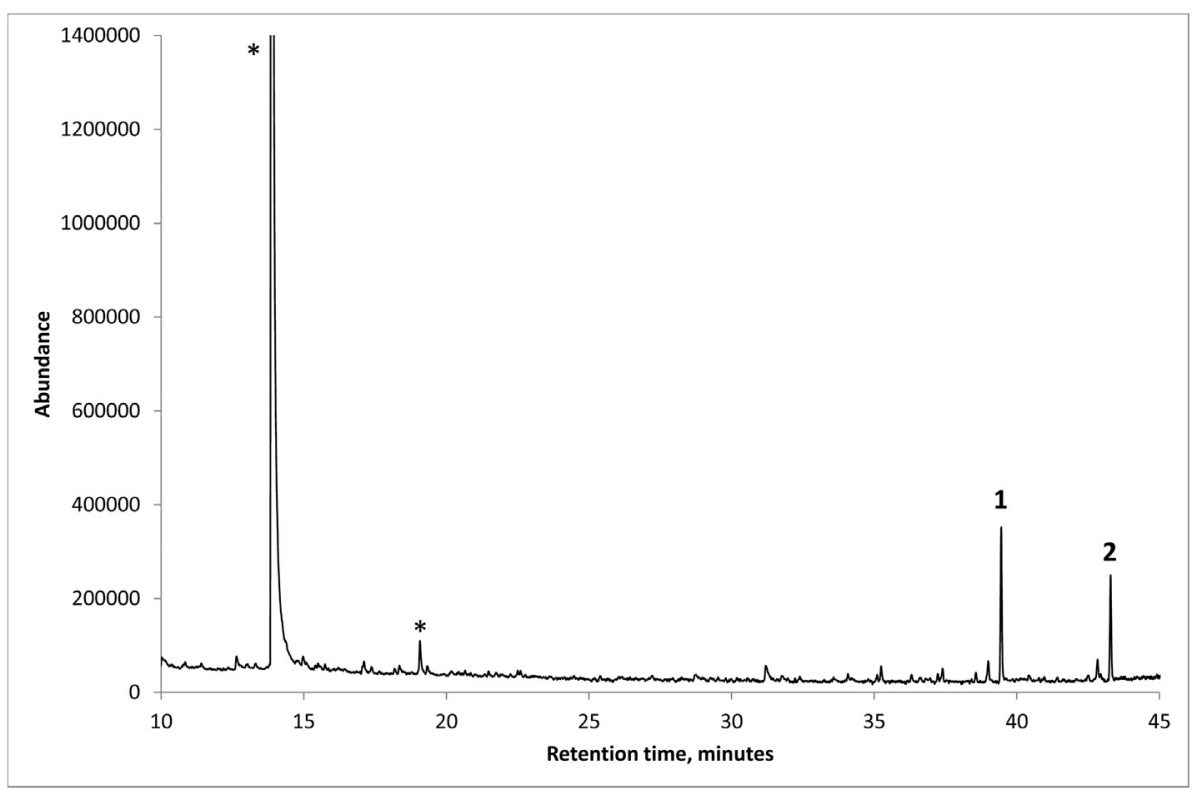

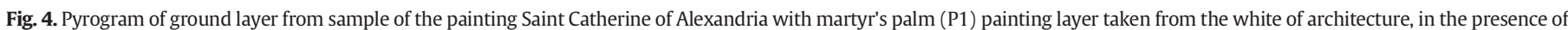
TMAH derivatization reagent, suggesting the presence of linseed oil as binder. Peak identification as follows: (1) Palmitic acid, (2) Stearic acid, ( $\left.{ }^{*}\right)$ TMAH pyrolysis products.

Anhydrite is set up with the $1014 \mathrm{~cm}^{-1}$ band for a symmetrical stretching of the SO4 group and $672,613 \mathrm{~cm}^{-1}$ at antisymmetric bending vibrations.

It is possible to find affinities concerning ground layers when comparing Goa Cathedral former altarpiece (A1) to other paintings assigned to Garcia Fernandes.

The ground layers of the paintings of the altarpiece of the chapel of Bartolomeu Joanes (A3) are double-layered, with the upper layers thinly ground than the coarser layers, placed closest to the support. The inorganic composition of these ground layers varies: in Martyrdom of St. Bartholomew, a mixture of calcium sulfate and calcium carbonate is found, and black particles, probably of bone black, are also observed. The semi-quantitative results obtained by $\mu$-DRX showed contradictory outcome, with one of the samples having a minimum percentage of gypsum (4\%) compared to anhydrite (96\%). On other samples analyzed $44 \%$ of gypsum and $36 \%$ of anhydrite, with $20 \%$ of quartz and calcite were found. These facts indicate the presence of thick (gesso grosso) and fine (gesso mate) calcium sulfate in the double ground layer (Figs. 5a and b). Analysis by $\mu$-Raman confirmed the presence of anhydrite (main peak at $1017 \mathrm{~cm}^{-1}$ ). SEM-EDS technique identified the following elements: $\mathrm{S}$ and $\mathrm{Ca}$, in all probability due to calcium sulfate, as well as $\mathrm{Na}, \mathrm{Si}, \mathrm{Al}, \mathrm{Mg}, \mathrm{Fe}, \mathrm{Cl}, \mathrm{K}$ and $\mathrm{Ti}$, originating from a likely mixture of calcium sulfate and $\mathrm{K}, \mathrm{Fe}$ and $\mathrm{Mg}$ aluminosilicates, with grains composed mainly of $\mathrm{K}$, Fe and $\mathrm{Mg}$. There are grains composed mainly of $\mathrm{Fe}$, probable oxide-hydroxides, which give ochre color to the ground layer and grains of Ca, probably due to calcite (Fig. $5 \mathrm{c}$ ). The $\mu$-FTIR spectrum indicates the presence of gypsum (3546 and $3404 \mathrm{~cm}^{-1} \mathrm{\nu OH}$, $1621 \mathrm{~cm}^{-1} \delta \mathrm{OH}, 1155 \mathrm{~cm}^{-1} v_{\text {asSO4 }}$ and $\left.677 \mathrm{~cm}^{-1} \delta \mathrm{SO} 4\right)$, as well as fatty acids from oil $\left(2930 \mathrm{~cm}^{-1}\right.$ vas $\mathrm{CH}, 2854 \mathrm{~cm}^{-1} \nu \mathrm{CH}$ and $1721 \mathrm{~cm}^{-1}$ $\nu \mathrm{CO}$ )and proteins (probably animal glue,).

The two small bands at 1541 and $1652 \mathrm{~cm}^{-1}$ are assigned to the $\mathrm{N}-\mathrm{H}$ bending and $\mathrm{C}-\mathrm{N}$ (amide II) stretching and $\mathrm{C}=\mathrm{O}$ stretching (amide I) respectively, as well as the band at $1455 \mathrm{~cm}^{-1}$ (amide III) are associated with the presence of proteins most likely animal glue. It is possible to verify that the oil component is in majority when compared to the protein part (Fig. 6a).

In the tripartite predella of the Last Supper the ground layers were identified as having a matrix of calcium sulfate, to which were added yellow ochre, brown ochre and black bone, also incorporating aluminosilicates and grains of $\mathrm{Ca}$ and $\mathrm{Mg}$, probably dolomite. Up to four layers can be observed by OM in these grounds, with a thickness larger than $300 \mu \mathrm{m}$. Micro-XRD data ascertained a biggest quantity of anhydrite than gypsum in ground layers constitution, being considered as gesso grosso ground. Quartz was also identified by this technique, as well as
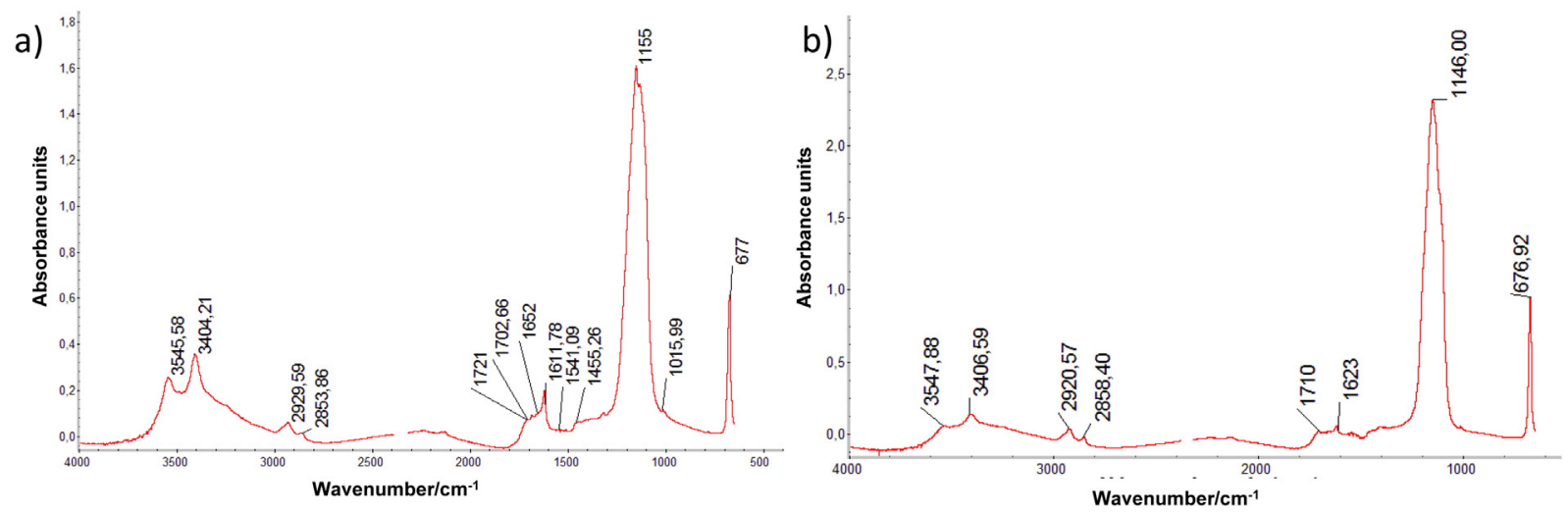

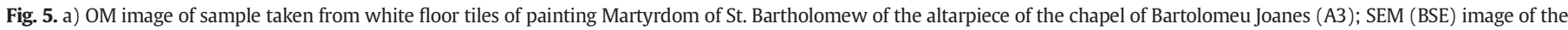

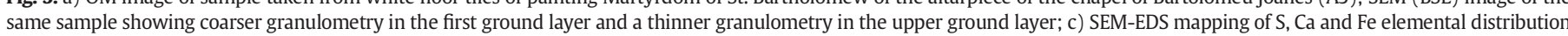
present in the same sample. 
a)

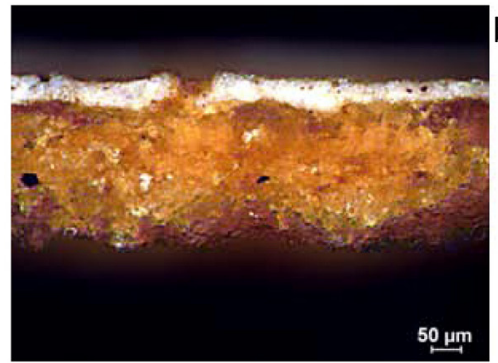

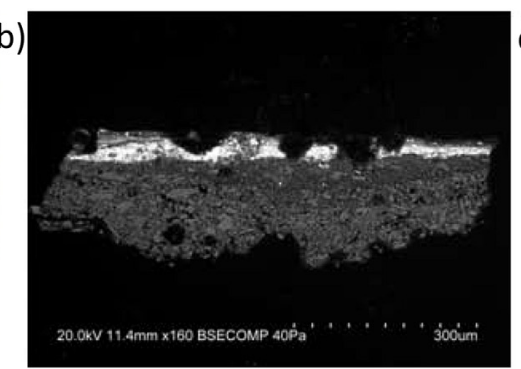

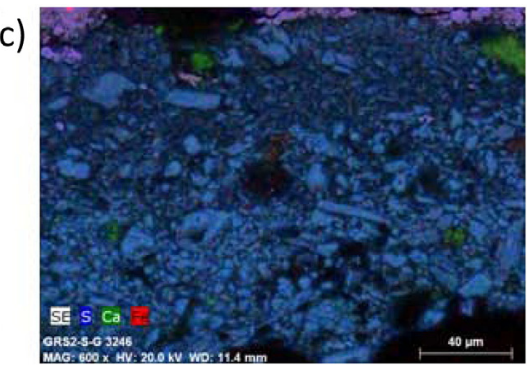

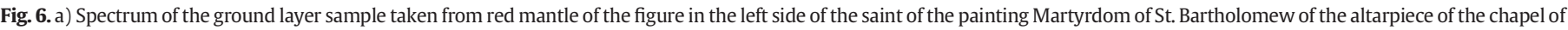

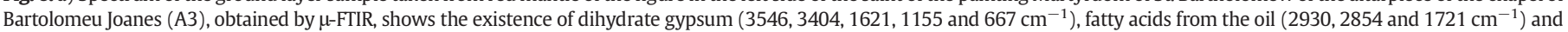

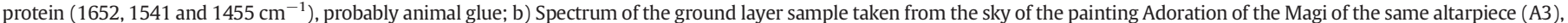
obtained by $\mu$-FTIR, shows the existence of dihydrate gypsum (3547, 3407, 1623, 1146 and $667 \mathrm{~cm}^{-1}$ ) and fatty acids from the oil (2921, 2858 and $1710 \mathrm{~cm}-1$ ).

calcite. The analysis by $\mu$-Raman confirmed the presence of anhydrite (main peak at $1017 \mathrm{~cm}^{-1}$ ) and calcite (main peak at $1088 \mathrm{~cm}^{-1}$ ). SEM-EDS showed the presence of $\mathrm{S}, \mathrm{Ca}, \mathrm{Si}, \mathrm{Al}, \mathrm{Mg}, \mathrm{Fe}, \mathrm{Cl}, \mathrm{K}$, Ti and $\mathrm{Ca}$, as well as $\mathrm{Pb}$, originated from a probable mixture with calcium sulfate and aluminosilicates of $\mathrm{K}, \mathrm{Fe}$ and $\mathrm{Mg}$, being grains composed mainly by Fe, possible Fe oxide-hydroxides. These grains provide an ochre color to the ground layer; carbonates were also confirmed, with the presence of $\mathrm{Ca}$, but also trace amounts of $\mathrm{Mg}, \mathrm{Fe}, \mathrm{K}, \mathrm{Al}$, Si and $\mathrm{P}$, the latter possibly related to bone black pigment. $\mathrm{Pb}$ is probably originated from the addition of lead carbonate to the ground layer, fact that differentiates this painting from $A 1$, since this material was not found. It was also detected the presence of grains of $\mathrm{Sr}$ and a small percentage of $\mathrm{Ba}$, which may correspond to celestite, as in the case of A1. The right lateral predella differs from the central predella because the $\mathrm{Sr}$ grains found in it do not contain $\mathrm{Ba}$, and the presence of $\mathrm{Pb}$ is not detected either. Considering these two aspects, one can consider the hypothesis that the ground layers may have been made in different timings. The Pb identified is probably due to the addition of lead carbonate dissolved in the ground layer. Regarding the binders of the predella ground layers, the presence of animal glue and oil had been already identified by $\mu$-FTIR [18]. In the lateral paintings (Lamentation, Adoration of the Magi, Annunciation and Nativity), the matrix of the ground layers is also calcium sulfate, with yellow and brown ochres and black grains, probably black bone, being punctually added lead white [19]. The results of $\mu$-XRD in the Adoration of the Magi painting show that the percentage of anhydrite is much higher than that of gypsum, and no other compounds have been identified in this ground layer. As such, only anhydrite (main peak at $1018 \mathrm{~cm}^{-1}$ ) was identified in the $\mu$-Raman analysis [35]. SEM-EDS showed the presence of $\mathrm{S}$ and $\mathrm{Ca}$, in all probability due to calcium sulfate, as well as $\mathrm{S}, \mathrm{Na}, \mathrm{Si}, \mathrm{Al}, \mathrm{Mg}, \mathrm{Fe}, \mathrm{Cl}, \mathrm{K}$ and $\mathrm{Ti}$, elements most probably derived from aluminosilicates of $\mathrm{K}, \mathrm{Mg}$ and $\mathrm{Fe}$, giving ochre color to the ground layer. It was put in evidence the occurrence of carbonates with the presence of $\mathrm{Ca}$ and trace amounts of $\mathrm{Mg}, \mathrm{Fe}, \mathrm{K}$,
$\mathrm{Al}, \mathrm{Si}$ and $\mathrm{Pb}$, probably from an addition of a lead carbonate dissolved in the ground layer. Sr was also detected with a small percentage of $\mathrm{Ba}$, being probably celestite. The occurrence of Ba suggests the relation of this painting to the central predella of the set and also to painting A1.

The spectra obtained by $\mu$-FTIR reveals the presence of gypsum (3547 and $3407 \mathrm{~cm}^{-1} \nu \mathrm{OH}, 1623 \mathrm{~cm}^{-1} \delta \mathrm{OH}, 1146 \mathrm{~cm}^{-1}$ vasSO 4 and $\left.677 \mathrm{~cm}^{-1} \delta \mathrm{SO} 4\right)$ and fatty acids from the oil $\left(2921 \mathrm{~cm}^{-1}\right.$ vas $\mathrm{CH}$, $2858 \mathrm{~cm}^{-1} \nu \mathrm{CH}$ and $1710 \mathrm{~cm}^{-1} \nu \mathrm{CO}$ ), but the likely presence of animal glue protein is not sufficient to be detectable in the studied samples (Fig. 6 b).

In the painting Our Lady of the Assumption (A2), a double ground layer is observed by OM and SEM (Figs. 7a and b), the lower layer being in a lighter color than the upper layer, where a higher concentration of ochre-colored grains is observed by OM, which makes it yellowish; elemental map of SEM-EDS indicates the presence of the elements $S$ and $\mathrm{Ca}$, due to calcium sulfate, as well as $\mathrm{S}, \mathrm{Si}, \mathrm{Al}, \mathrm{Mg}, \mathrm{Fe}, \mathrm{Cl}, \mathrm{K}$, and $\mathrm{Ca}$, corresponding to a probable mixture with calcium sulfate and aluminosilicates of $\mathrm{K}$, Fe and $\mathrm{Mg}$; Fe is especially in the upper part of the ground layer, in a finer granulometry. It is found, however, ochre grains and black grains in both layers. The lower layer consists of coarser grains, and the cracking of the anhydrite grains caused by its calcination is observed through SEM images. The top layer is made with the same finerground material. It is possible to find traces of sizing and also a polishing layer. The thickness of each ground layer exceeds $100 \mu \mathrm{m}$. Micro-XRD analysis shows that the percentage of anhydrite is much higher than that of gypsum, being also identified the quartz in its constitution. Analysis by $\mu$-Raman confirmed the presence of anhydrite (main peak at $\left.1017 \mathrm{~cm}^{-1}\right)$. The spectra obtained by $\mu$-FTIR, shows the presence of gypsum ( 3540 and $3404 \mathrm{~cm}^{-1} \nu \mathrm{OH}, 1617 \mathrm{~cm}^{-1} \delta \mathrm{OH}, 1142 \mathrm{~cm}^{-1}$ vasSO 4 and $\left.668 \mathrm{~cm}^{-1} \delta \mathrm{SO} 4\right)$ and fatty acids of the oil $\left(2930 \mathrm{~cm}^{-1}\right.$ vas $\mathrm{CH}$, $2854 \mathrm{~cm}^{-1} \nu \mathrm{CH}$ and $1708 \mathrm{~cm}^{-1} \nu \mathrm{CO}$ ) (. The two small bands at 1541 and $1647 \mathrm{~cm}^{-1}$ respecting the $\mathrm{N}-\mathrm{H}$ bending and $\mathrm{C}-\mathrm{N}$ (amide II) stretching and $\mathrm{C}=\mathrm{O}$ stretching (amide $\mathrm{I}$ ) respectively and the 1450 a)

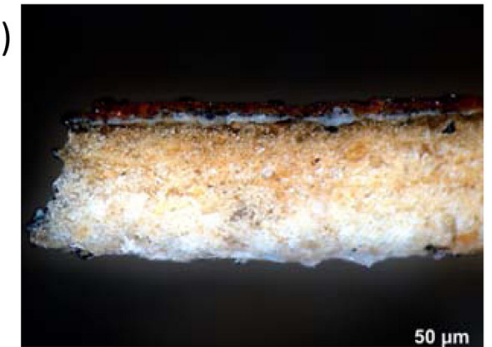

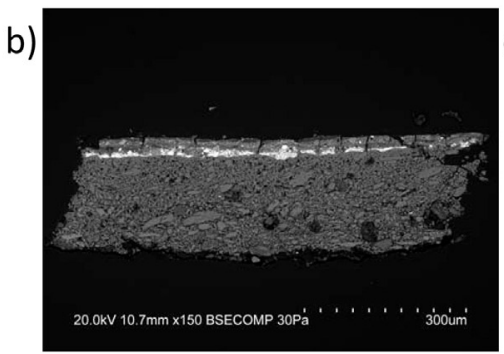

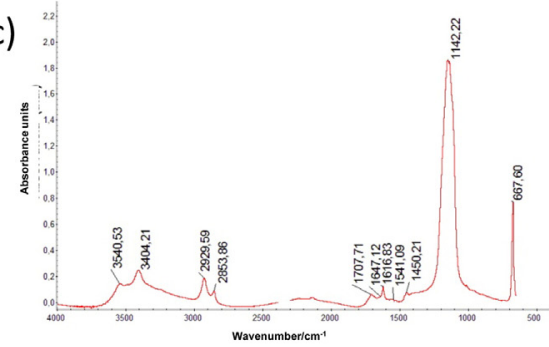

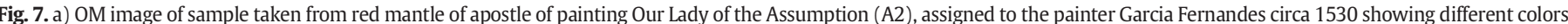

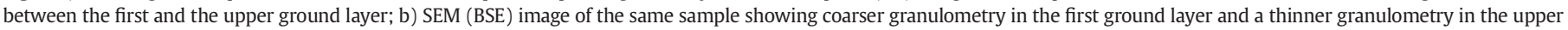

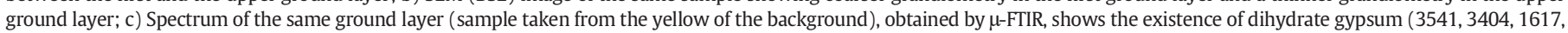
1142 and $\left.668 \mathrm{~cm}^{-1}\right)$, fatty acids from the oil $\left(2930,2854\right.$ and $\left.1708 \mathrm{~cm}^{-1}\right)$ and protein $\left(1647,1541\right.$ and $\left.1450 \mathrm{~cm}^{-1}\right)$, probably animal glue. 
$\mathrm{cm}^{-1}$ (amide III) band are associated with the presence of protein, in this case animal glue. The oil component is predominant compared to the protein component, due to the greater relative ease in identifying the oil (Fig. 7c). The painting Testimony of St. John the Baptist with the priests and Levites of Jerusalem (A4) also has a double ground layer, although the difference in the milling of the layers is not so evident. The $\mu$-XRD analysis demonstrates that the percentage of anhydrite is much higher than that of gypsum, and also identified calcite and quartz as a constituent of the ground layers. Analysis by $\mu$-Raman also confirmed the presence of anhydrite (main peak at $1017 \mathrm{~cm}^{-1}$ ) and gypsum (main peak at $1007 \mathrm{~cm}^{-1}$ ). The following elements were identified by SEM-EDS: $\mathrm{S}$ and Ca, probably due to calcium sulfate, $\mathrm{Na}, \mathrm{S}, \mathrm{Cl}$, $\mathrm{Pb}, \mathrm{Si}, \mathrm{Al}, \mathrm{Mg}, \mathrm{Fe}, \mathrm{K}$, Ti and $\mathrm{P}$, elements originated from a probable mixture including calcium sulfate and $\mathrm{K}, \mathrm{Fe}$ and $\mathrm{Mg}$ aluminosilicates, with $\mathrm{Pb}$ being a likely addition of lead carbonate to the ground layer and $\mathrm{P}$ possibly related to the presence of bone black. The presence of grains of $\mathrm{Sr}$ may suggest the occurrence of celestite; in these grains a small amount of Ba may also occur (Figs. 8 a and b). Spectra obtained by $\mu$ FTIR, identifies gypsum (3542 and $3401 \mathrm{~cm}^{-1} \nu \mathrm{OH}, 1621 \mathrm{~cm}^{-1} \delta \mathrm{OH}$, 1157 and $1127 \mathrm{~cm}^{-1}$ vasSO 4 and $671 \mathrm{~cm}^{-1} \delta \mathrm{SO} 4$ )and oil fatty acids (2932 $\mathrm{cm}^{-1}$ vas $\mathrm{CH}, 2853 \mathrm{~cm}^{-1} \nu \mathrm{CH}$ and $1700 \mathrm{~cm}^{-1} \nu \mathrm{CO}$ ) (Fig. $8 \mathrm{c}$ ).

\subsection{Underdrawing}

The drawing of Goa Cathedral former altarpiece (A1) is made of carbon black, probably lamp black, since P was not found by SEM-EDS analysis in these grains. The paintings from this altarpiece (A1) show a vigorous drawing, by wet brush, marking shadows, light areas and also with abandoned drawing and changes. It is possible to verify by infrared reflectography technique that the painting Saint Catherine of Alexandria with martyr's palm (P1) was one of the most changed during the drawing process, presenting a big quantity of abandoned drawing, probably due to the importance of the theme to the commissioner, emphasizing the triumph of the catholic Saint over the pagan emperor. Some of the drawing changes in this set of paintings are possible to identify by macro photography, IRR and IR photography and even by naked eye due to the aging of its constituent materials (Fig. 9).

The Lisbon Cathedral altarpiece of the chapel of Bartolomeu Joanes (A3) reflectography shows a minutiae preparatory drawing, made with black carbon, marking the shadows and light areas, such as the details of each figure's faces and draperies $[18,19]$.

The painting Our Lady of the Assumption (A2) has a vigorous underdrawing using lamp black as drawing material [43].

The reflectographic examination of the painting Testimony of Saint John the Baptist with the priests and Levites of Jerusalem (A4) shows a detailed carbon black underdrawing, with careful marking of the shadows, with crossed lines, being the faces executed with an elaborate and vigorous sketch [22].

\subsection{Priming layer}

Considered the first paint layers, primings of the painting Saint Catherine of Alexandria with martyr's palm (P1), are partial. Micro-Raman has showed that lead white (main peak at $1056 \mathrm{~cm}^{-1}$ ) is the main pigment in the primings.

Comparing priming layers with other works assigned to the artist it is possible to find parallels in partial primings. The white layer is found under brown and red color, as in the same colors of the other studied paintings of this workshop. In the painting Martyrdom of St. Bartholomew from Lisbon Cathedral altarpiece of the chapel of Bartolomeu Joanes (A3) primings are also partial: under the brown colors, a chalk layer can be found, and underneath the yellow colors, in a matrix of lead white, a mixture of carbon black, ochre and vermilion can be also found [18].

The material analysis of the painting Our Lady of the Assumption (A2) has shown that partial priming layers in a matrix of lead white can be found under brown, blue and red colors [43].

In the painting Testimony of Saint John the Baptist with the priests and Levites of Jerusalem (A4) it is possible to verify that the blue of the sky and the red of the priest's mantle have a first lead white layer, a probable priming (Fig. 8a) [44].

\subsection{Pigments and painting layers stratigraphic technique}

The painting technique of Saint Catherine of Alexandria with martyr's palm (P1) is composed in light tones by adding lead white or lead-tin yellow to enlighten each color. In shadow tones lamp black was possibly mixed with Verdete (verdigris), since this pigment was described by ancient Portuguese treatises as a siccative of black pigments $[41,45]$. Cu element was found by XRF in shadow tones of the colors of the paintings studied of this altarpiece.

Table 1 resumes the XRF Key-elements of the studied paintings of Goa Cathedral former altarpiece (A1) (paintings 1 to 5: Saint Catherine of Alexandria with martyr's palm (P1), The Assumption of St. Catherine of Alexandria (P2), The Beheading of St. Catherine of Alexandria (P3), St. Catherine survival of death by a spiked wheel (P4) and St. Catherine imprisonment by the Emperor (P5)), having the same key-elements by color than the painting of Saint Catherine of Alexandria with martyr's palm (P1).

Lead white (main peak at $1051 \mathrm{~cm}^{-1}$ ) is the main pigment in white color, along with carbon black (main peaks at 1380 and $1600 \mathrm{~cm}^{-1}$ ) as settled by $\mu$-Raman. XRF ascertained and confirmed the presence of $\mathrm{Pb}$ and Ca elements; Carbon grains were identified by SEM-EDS analysis, being probably lamp black since $P$ was absent in these black particles. Micro-FTIR identified the presence of hydrocerussite and kaolinite, most likely used as filler to increase plasticity in white layer [46], also as oil and protein (possibly animal glue tempera) as binders. Hydrocerussite $\left(\mathrm{Pb}_{3}\left(\mathrm{CO}_{3}\right)_{2}(\mathrm{OH})_{2}\right)$ can be found at hydration
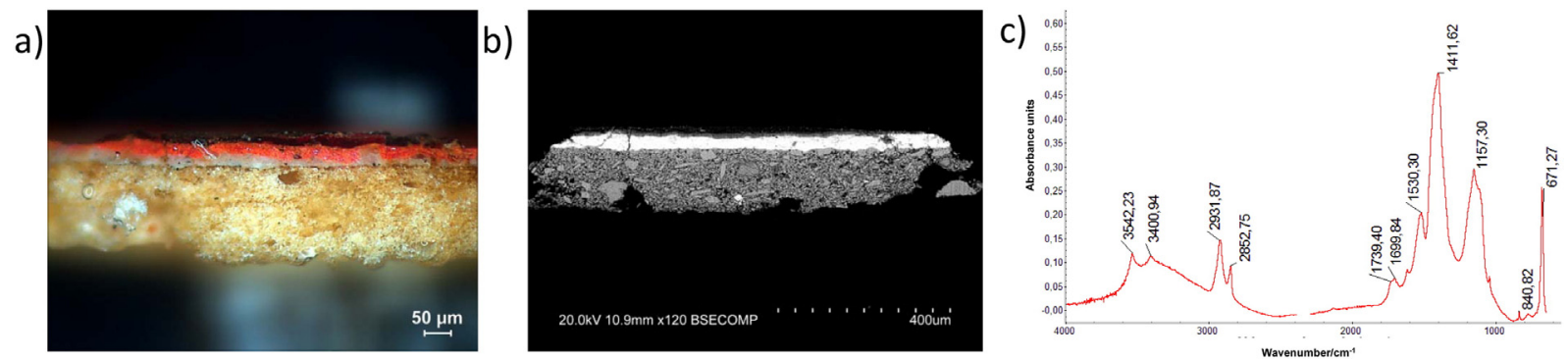

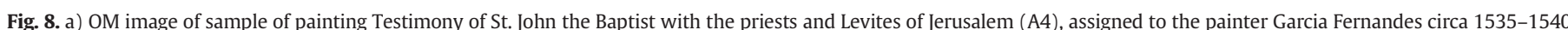

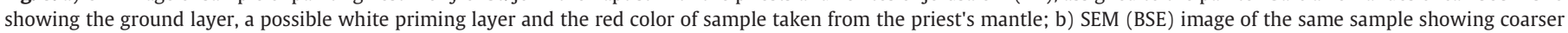

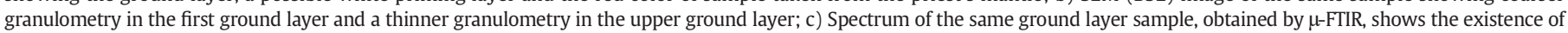
dihydrate gypsum $\left(3542,3401,1621,1157,1127\right.$ and $\left.671 \mathrm{~cm}^{-1}\right)$ and fatty acids from the oil $\left(2932,2853\right.$ and $\left.1700 \mathrm{~cm}^{-1}\right)$. 
a)

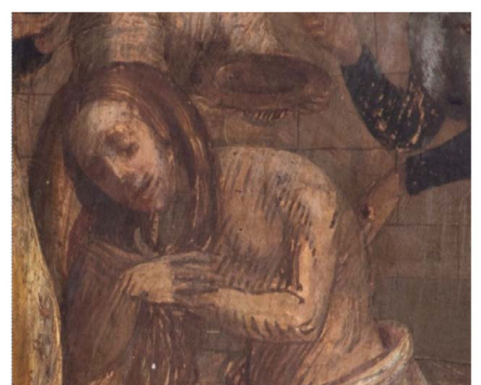

b)

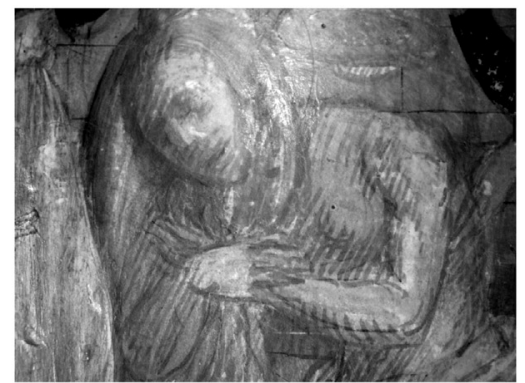

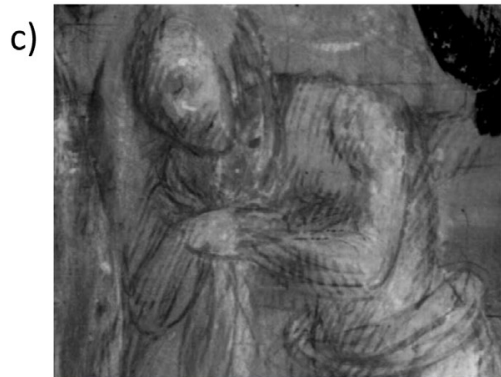

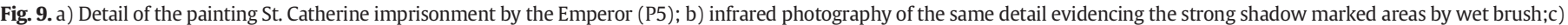
infrared reflectography of the same detail evidencing the same drawing marks.

absorption band at $3525 \mathrm{~cm}^{-1}, 1405(\mathrm{CO} 3)^{2-}$ stretching and $\mathrm{O}-\mathrm{H}$ bending vibration at $1045 \mathrm{~cm}^{-1}$ and $4(\mathrm{CO} 3)^{2-}$ bending modes at 837 and $680 \mathrm{~cm}^{-1}$. Kaolinite $\left(\mathrm{Al}_{2} \mathrm{O}_{3} \cdot 2 \mathrm{SiO}_{2} \cdot 2 \mathrm{H}_{2} \mathrm{O}\right)$ has characteristic bands at $3696 \mathrm{~cm}^{-1}$ assigned to $\mathrm{Al}-\mathrm{O}-\mathrm{H}$ stretching and $637 \mathrm{~cm}^{-1}$ assigned to $\mathrm{Si}-\mathrm{O}$ bending [47]. Proteins are visible at $1539 \mathrm{~cm}^{-1}$ corresponding to an $\mathrm{N}-\mathrm{H}$ bending and $\mathrm{C}-\mathrm{N}$ stretching (amide II) and $1446 \mathrm{~cm}^{-1}$ (amide III). The bands at 2924 and $2851 \mathrm{~cm}^{-1}$ are linked with an $\mathrm{C}-\mathrm{H}$ stretching comparative to the fatty acid hydrocarbon chains and at $1702 \mathrm{~cm}^{-1}$ are due to an stretching of the $\mathrm{C}=0$ carbonyl group of the fatty acids. The coexistence of proteins and oil in the painting layer characterizes these paintings as a mixed media technique. It was also found wax, probably an intervention product. Wax bands can be established at 2924 and $2851 \mathrm{~cm}^{-1}$, related with an C-H stretching relative to the fatty acid hydrocarbon chains, at 1702 and $1164 \mathrm{~cm}^{-1}$ suitable to the stretching of the $\mathrm{C}=\mathrm{O}$ carbonyl group of the fatty acids and the band at $730 \mathrm{~cm}^{-1}$ is owing to $\mathrm{C}-\mathrm{H}$ bending (Fig. 10).

Proteins, in all probability animal glue were also detected by $\mu$-FTIR technique in the white color of the painting Martyrdom of St. Bartholomew from Lisbon Cathedral altarpiece of the chapel of Bartolomeu Joanes (A3) [18].

Yellow colors are mainly built up with lead-tin yellow and ochre pigments, as in other paintings studied from this artist's workshop [43]. These lead-tin yellow colors are mostly exclusive of the detailed miniature representation of golden objects, such as Saint Catherine's crown or belt, showing the minutia of the painter's brush technique(Fig. 1). XRF key-elements are $\mathrm{Sn}, \mathrm{Pb}, \mathrm{Fe}, \mathrm{Cu}$ and $\mathrm{Hg}$. SEM-EDS elements found in grains of yellow colors were $\mathrm{Sn}$ and $\mathrm{Pb}$ belonging to lead-tin yellow type I (main peaks at 133, 201 and $273 \mathrm{~cm}^{-1}$ ) which was identified by $\mu$-Raman; black grains of $C$ are probably lamp black since no $P$ was found in these particles. It was also found $\mathrm{Cu}$ with $\mathrm{Al}$ disseminated in the yellow layer matrix, being the first probably from a green $\mathrm{Cu}$ pigment (verdigris or copper resinate) and Al originating possibly from alum, used as a fixative for dyes; Fe derived from goethite (main peaks at 306, 402, 479 and $557 \mathrm{~cm}^{-1}$ ) and hematite (main peaks at $228,295,414$ and $612 \mathrm{~cm}^{-1}$ ) was confirmed by $\mu$-Raman. With this technique it was also possible to confirm the presence of calcium carbonate (main peak at $1089 \mathrm{~cm}^{-1}$ ), anhydrite (main peak at $1007 \mathrm{~cm}^{-}$ ${ }^{1}$ ), vermilion (main peaks at 250 and $343 \mathrm{~cm}^{-1}$ ), lamp black(main peaks at 1301 and $1612 \mathrm{~cm}^{-1}$ ) and a green pigment as complements of yellow layers. This pigment, such as some dyes in these paintings, was not possible to identify by HPLC/DAD/MS or $\mu$-Raman due to the low quantity existent in the different color layers.

Blue color is mainly composed by azurite. XRF identified the presence of $\mathrm{Pb}$ and $\mathrm{Cu}$ elements. These elements were also highlighted by SEM-EDS technique, along with different grains containing Fe and C. As established by $\mu$-Raman technique $\mathrm{Pb}$ was related to lead white (main peak at $1049 \mathrm{~cm}^{-1}$ ), Cu to azurite(main peaks at 401 and 1102 $\mathrm{cm}^{-1}$ ), Fe to hematite (main peaks at 228,272 and $415 \mathrm{~cm}^{-1}$ ) and $\mathrm{C}$ to carbon black (main peaks at 1381 and $1599 \mathrm{~cm}^{-1}$ ). In these last grains $P$ was absent in SEM-EDS analysis, indicating the use of lamp black. Micro-FTIR technique confirmed the presence of azurite, cerussite, hydrocerussite, oil and lead carboxylates, the latter probably originated

Table 1

Analytical results identifying elemental, chemical composition and mixture of pigments.

\begin{tabular}{|c|c|c|c|c|c|c|}
\hline Color & $\begin{array}{l}\text { XRF } \\
\text { Key-elements } \\
\text { (paintings } 1 \\
\text { to 5) }\end{array}$ & $\begin{array}{l}\text { Area } \\
\text { (painting 1) }\end{array}$ & $\begin{array}{l}\text { SEM-EDS } \\
\text { key-elements } \\
\text { (painting 1) }\end{array}$ & $\begin{array}{l}\mu \text {-Raman compounds (wavenumbers are in } \mathrm{cm}^{-1} \text { ) } \\
\text { (painting } 1 \text { ) }\end{array}$ & $\begin{array}{l}\text { Main } \\
\text { pigments } \\
\text { by color } \\
\text { (painting 1) }\end{array}$ & $\begin{array}{l}\text { Mixture of pigments by color } \\
\text { (painting 1) }\end{array}$ \\
\hline Yellow & $\begin{array}{l}\mathrm{Sn}, \mathrm{Pb}, \mathrm{Fe}, \mathrm{Cu} \\
\mathrm{Hg}\end{array}$ & Saint bodice & $\begin{array}{l}\mathrm{Sn}, \mathrm{Pb}, \mathrm{Fe}, \mathrm{C} \\
\mathrm{Cu}\end{array}$ & $\begin{array}{l}\text { Lead-tin yellow type I }(133,201,273) \text {, anhydrite }(1007) \text {, } \\
\text { hematite }(228,295,414,612) \text {, calcium carbonate }(1089) \text {, } \\
\text { goethite }(306,402,479,557) \text {, vermilion }(250,343) \text {, lamp black } \\
(1301,1612)\end{array}$ & $\begin{array}{l}\text { Lead-tin } \\
\text { yellow, } \\
\text { ochre }\end{array}$ & $\begin{array}{l}\text { Lead-tin yellow }+ \text { lead white }+ \\
\text { vermilion }+ \text { anhydrite }+ \text { calcite }+ \\
\text { yellow ochre }+ \text { red ochre }+ \text { green } \\
\text { pigment }+ \text { lamp black }\end{array}$ \\
\hline Blue & $\mathrm{Pb}, \mathrm{Cu}$ & Sky & $\mathrm{Pb}, \mathrm{Cu}, \mathrm{Fe}, \mathrm{C}$ & $\begin{array}{l}\text { Hematite }(228,272,415) \text {, azurite }(401,1022) \text {, lead white } \\
\text { (1049), carbon black }(1381,1599)\end{array}$ & Azurite & $\begin{array}{l}\text { Azurite }+ \text { lead white }+ \text { lamp black } \\
+ \text { red ochre }\end{array}$ \\
\hline White & $\mathrm{Pb}, \mathrm{Ca}$ & Architecture & $\mathrm{Pb}, \mathrm{C}$ & Lead white $(1051)$, carbon black $(1380,1600)$ & Lead white & Lead white + lamp black \\
\hline Brown & $\mathrm{K}, \mathrm{Mn}, \mathrm{Fe}, \mathrm{Cu}$ & Architecture & $\mathrm{Fe}, \mathrm{C}$ & $\begin{array}{l}\text { Hematite }(228,246,295,412,495,615), \text { carbon black }(1379 \text {, } \\
1599) \text {, calcium carbonate }(1085)\end{array}$ & $\begin{array}{l}\text { Red ochre, } \\
\text { lamp black }\end{array}$ & $\begin{array}{l}\text { Red ochre }+ \text { calcium carbonate }+ \\
\text { lamp black }\end{array}$ \\
\hline Black & $\mathrm{K}, \mathrm{Fe}, \mathrm{Cu}$ & Book & $\begin{array}{l}\mathrm{C}, \mathrm{Cu}, \mathrm{Fe}, \mathrm{Al} \\
\mathrm{S}, \mathrm{K}\end{array}$ & $\begin{array}{l}\text { Carbon black }(1320,1601) \text {, Azurite }(250,1098) \text {, lead white } \\
(1052)\end{array}$ & Lamp black & $\begin{array}{l}\text { Lamp black }+ \text { green pigment }+ \text { red } \\
\text { dye }\end{array}$ \\
\hline Green & $\mathrm{Fe}, \mathrm{Cu}$ & Architecture & $\mathrm{Cu}, \mathrm{Hg}, \mathrm{Fe}$ & $\begin{array}{l}\text { Azurite }(250,400,830,1097) \text {, lead white }(1050), \text { carbon black } \\
(1380,1600)\end{array}$ & $\begin{array}{l}\text { Azurite, } \\
\text { lead white, } \\
\text { green } \\
\text { pigment }\end{array}$ & $\begin{array}{l}\text { Azurite }+ \text { leadwhite }+ \text { green } \\
\text { pigment }\end{array}$ \\
\hline Red & $\mathrm{Fe}, \mathrm{Hg}$ & Mantle & $\mathrm{Fe}, \mathrm{Hg}, \mathrm{C}, \mathrm{Al}, \mathrm{S}$ & $\begin{array}{l}\text { Vermilion }(252,343) \text {, hematite }(285,492,612) \text { carbon black } \\
(1379,1600)\end{array}$ & $\begin{array}{l}\text { Vermilion, } \\
\text { red ochre } \\
\text { red dye }\end{array}$ & $\begin{array}{l}\text { Vermilion }+ \text { red ochre }+ \text { lamp } \\
\text { black }+ \text { red dye }\end{array}$ \\
\hline Carnation & $\mathrm{Hg}, \mathrm{Fe}, \mathrm{Pb}, \mathrm{Cu}$ & Saint & $\begin{array}{l}\mathrm{Hg}, \mathrm{Sn}, \mathrm{Pb}, \mathrm{Al} \\
\mathrm{S}, \mathrm{C}, \mathrm{Cu}, \mathrm{Fe}\end{array}$ & $\begin{array}{l}\text { Lead white (1050), vermilion }(253,344) \text {, carbon black ( } 1380 \text {, } \\
1600) \text {, hematite }(227,246) \text {, lead-tin yellow }(134)\end{array}$ & $\begin{array}{l}\text { Vermilion, } \\
\text { ochre, red } \\
\text { dye }\end{array}$ & $\begin{array}{l}\text { Vermilion }+ \text { lampblack }+ \\
\text { leadwhite }+ \text { ochre }+ \\
\text { lead-tinyellow }+ \text { chalk }+ \text { reddye }+ \\
\text { green pigment }\end{array}$ \\
\hline
\end{tabular}




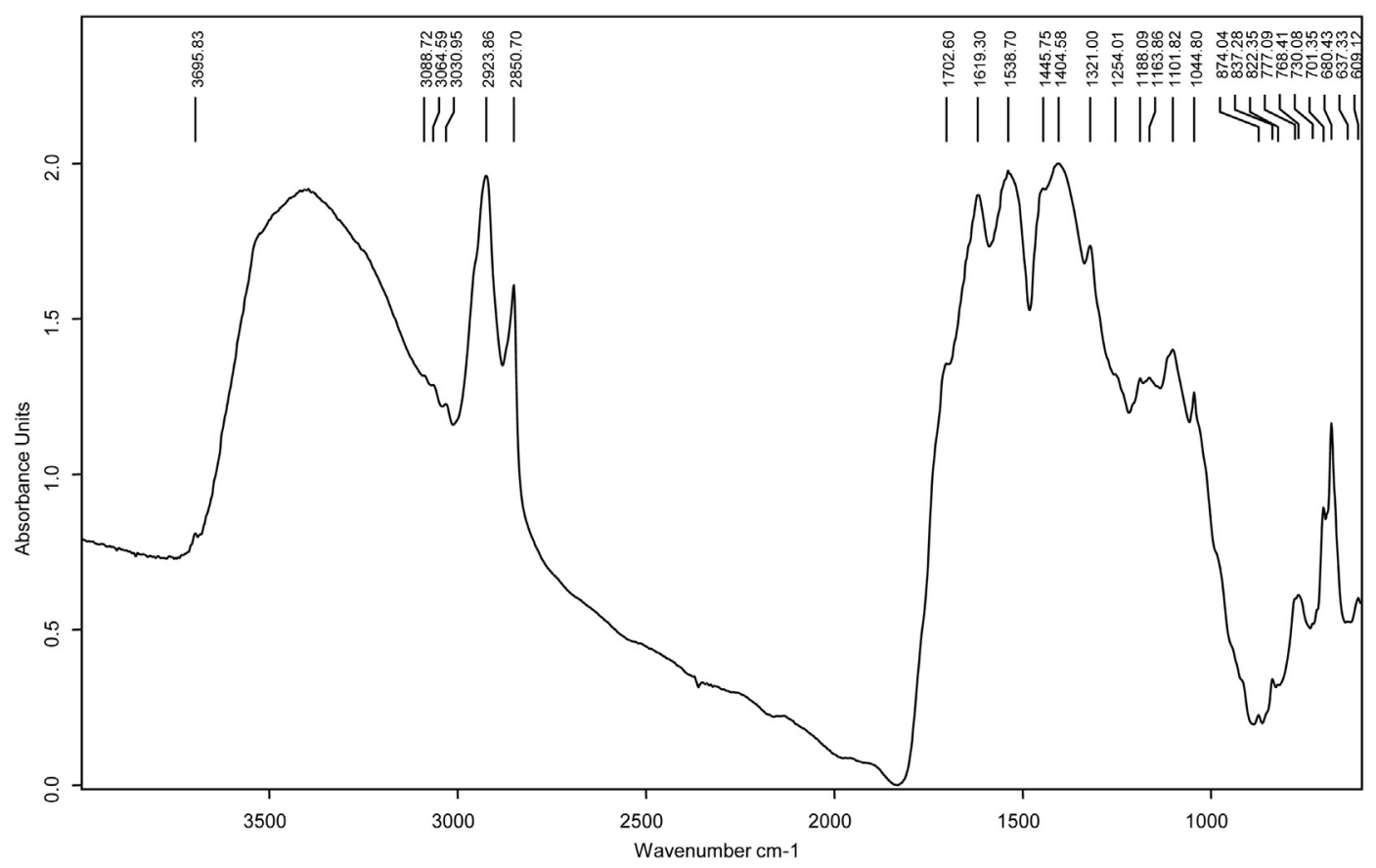

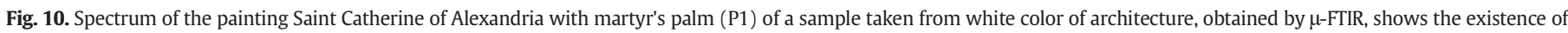

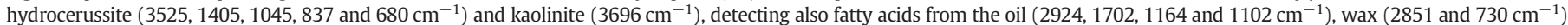
and protein $\left(1539,1446\right.$ and $\left.1254 \mathrm{~cm}^{-1}\right)$, probably animal glue.

by the degradation of lead white [46] (Fig. 11). Micro-FTIR revealed that the bands at 2924 and $2851 \mathrm{~cm}^{-1}$ correspond to an antisymmetric and symmetrical stretching, respectively, of $\mathrm{C}-\mathrm{H}$ bonds of alkyl groups, in addition to the stretching band $\mathrm{C}=\mathrm{O}$ at $1702 \mathrm{~cm}^{-1}$ designate the existence of oil. The bands for lead white can be found at 3538, 1396, $1050,1046,838$ and $680 \mathrm{~cm}^{-1}$. Azurite $\left(2 \mathrm{CuCO}_{3} \mathrm{Cu}(\mathrm{OH})_{2}\right)$ found at $3420 \mathrm{~cm}^{-1}$, characterized by $\mathrm{O}-\mathrm{H}$ stretching vibration, 943 and 824 $\mathrm{cm}^{-1}$ regions attributed to the $\nu 2$ and $\nu 4$ bending modes, being lead carboxylates at a strong absorption band of around $1519 \mathrm{~cm}^{-1}$.

Brown color is mainly built with red ochre (hematite, main peaks at $228,246,295,412,495$ and $615 \mathrm{~cm}^{-1}$ ) and carbon black (main peaks at 1379 and $1599 \mathrm{~cm}^{-1}$ ) pigments, also with grains of calcium carbonate (main peak at $1085 \mathrm{~cm}^{-1}$ ), as corroborated by $\mu$-Raman. The presence of calcium carbonate grains, probably used as a filler in certain mixtures

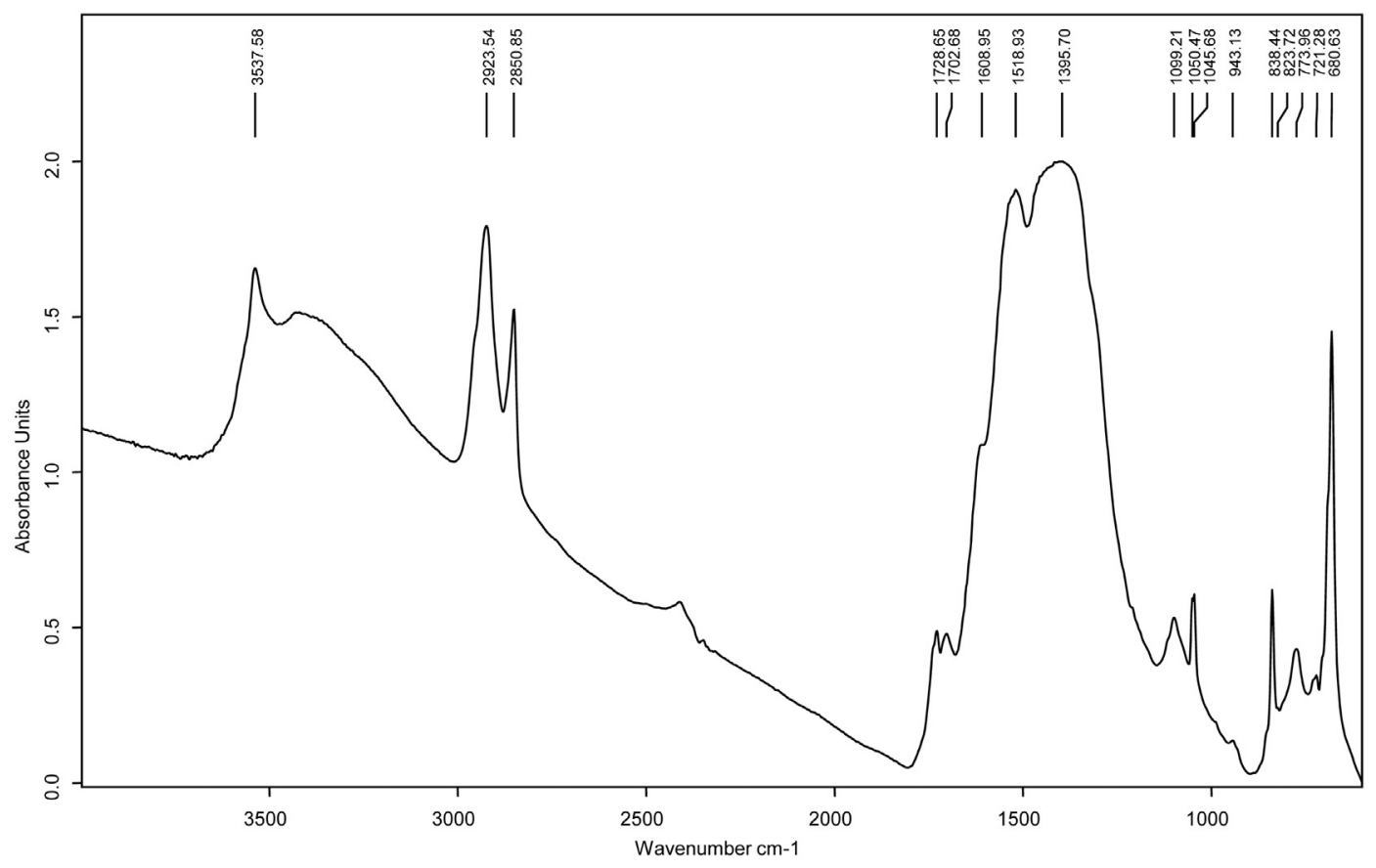

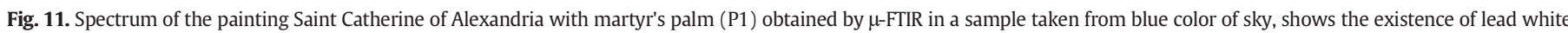
$\left(3538,1396,1050,1046,838\right.$ and $\left.681 \mathrm{~cm}^{-1}\right)$, azurite $\left(3420,943\right.$ and $\left.824 \mathrm{~cm}^{-1}\right)$, lead carboxylates $\left(1519 \mathrm{~cm}^{-1}\right)$ and fatty acids from the oil $\left(2924,2851,1099\right.$ and $\left.1703 \mathrm{~cm}^{-1}\right)$. 
of pigments has been also identified in the same color of the painting Martyrdom of St. Bartholomew from Lisbon Cathedral altarpiece of the chapel of Bartolomeu Joanes (A3). XRF technique shows the presence of the elements K, Mn and Fe probably due to aluminosilicates constituents of ochre pigments, and $\mathrm{Cu}$ disseminated through grains probably due to a non-identified green pigment, most likely verdigris. Also C grains were detected by SEM-EDS, probably due to lamp black pigment.

Red color is mainly composed of vermilion. We can observe this pigment mixed with red ochre, carbon black and also a non-identified reddye, possibly madder, as it was found in other paintings studied from the artist's workshop. XRF determined the presence of $\mathrm{Hg}$ and Fe elements due to vermilion (main peaks at 252 and $343 \mathrm{~cm}^{-1}$ ) and red ochre (hematite, main peaks at $285,492,612 \mathrm{~cm}^{-1}$ ) respectively, as endorsed by $\mu$-Raman, being also found carbon black (main peaks at 1379 and $1600 \mathrm{~cm}^{-1}$ ). The same layer overlapping technique is established in the painting Testimony of Saint John the Baptist with the priests and Levites of Jerusalem (A4): a lead white layer, a probable partial priming, under a layer of vermilion underlying a red dye, probably madder [44].

Carnation is mostly composed of vermilion (main peaks at 253 and $344 \mathrm{~cm}^{-1}$ ) and lead white (main peak at $1050 \mathrm{~cm}^{-1}$ ) with lead-tin yellow (main peak at $134 \mathrm{~cm}^{-1}$ ), red ochre(main peaks at 227 and 246 $\mathrm{cm}^{-1}$ ), lamp black(main peaks at 1380 and $1600 \mathrm{~cm}^{-1}$ ), calcium carbonate grains, a red dye and a green pigment. Red dye is possibly madder being the green pigment, possibly verdigris or copper resinate, as it was found in other paintings studied from the artist's workshop [43]. The elements $\mathrm{Hg}, \mathrm{Fe}, \mathrm{Pb}$ and $\mathrm{Cu}$ were established by XRF and also by SEM-EDS, identifying also grains with $\mathrm{Sn}$ and $\mathrm{Pb}$, determining the existence of leadtin yellow; $\mathrm{Cu}$ and $\mathrm{Al}$ together are possibly due to the mixture of a dye (containing $\mathrm{Al}$ as a fixative) to a green pigment, possibly verdigris.

Carbon black is also found in black color as its main pigment, being probably lamp black. XRF identified K, Fe and Cu elements and SEMEDS technique added to these last elements different grains with $C$, probably lamp black, since it was not detected the P element; also found by this technique were $\mathrm{Cu}$ and $\mathrm{Al}$ in the black matrix, the first being probably a non-identified green pigment, possibly verdigris and the latter a fixative component of a dye (Fig. 12).

This green pigment (probably verdigris or copper resinate) exists also in the green color, as shown by SEM-EDS by identifying $\mathrm{Cu}$ in the matrix and also $\mathrm{Al}$, probably originated from a dye mixture. Also, Fe is identified by this technique in all probability due to ochre grains. This element is also identified by XRF along with $\mathrm{Hg}$, almost certainly due to vermilion pigment. Micro-Raman verified the presence of azurite (main peaks at 250 and $1098 \mathrm{~cm}^{-1}$ ), lead white (main peak at 1052 $\mathrm{cm}^{-1}$ ) and carbon black (main peaks at 1320 and $1601 \mathrm{~cm}^{-1}$ ). The absence of mountain green, identified as being malachite, makes a difference when comparing the green color to the paintings of Lisbon Cathedral altarpiece of the chapel of Bartolomeu Joanes (A3) and Our
Lady of the Assumption (A2), having both malachite and being both assigned to the same epoch, circa 1530 . This pigment is not advised to use in oil painting, but only in tempera technique, by ancient Portuguese painting treatises $[41,45]$ due to its easy degradation and changing color with oil media. This could have been the cause of the non-identification of this pigment in the studied painting; since the artist most likely knew to where he was painting and that the paintings would suffer with the transportation, making them more resistant to environment changing. The malachite pigment has been also found in other Portuguese paintings from the same epoch and painted by Garcia Fernandes partners, as in the case of Gregório Lopes [27]. This aspect of the non-finding of malachite relates the studied paintings with Jorge Afonso painting technique, the headmaster of Lisbon workshop and master of Garcia Fernandes, since this pigment was also not found in the studied paintings from his workshop [47].

When comparing the material study of Goa Cathedral former altarpiece to other studied paintings assigned to Garcia Fernandes workshop, it is revealed that the same pigments and mixtures are used to make similar colors.

The Lisbon Cathedral altarpiece of the chapel of Bartolomeu Joanes (A3), constituted by eight panels, has already been studied in terms of materials $[18,19]$. The pigments found in the main painting, Martyrdom of St. Bartholomew are lead white, chalk and calcium sulfate, sometimes in mixture with bone black and vermilion, for white colors; in the red colors, both the red ochre and the vermilion, punctually mixed with bone black and with chalk. Azurite, sometimes in mixture with chalk and also the smalt mixed with vermilion, bone black, gypsum and ochre in the blue tones; brown and red ochre, also punctually with vermilion and sometimes in mixture with chalk, in brown colors. The carnations may contain ochre, vermilion, bone black or a mixture of gypsum, ochre, vermilion and possibly umber. Yellows have ochre, lead white and sometimes vermilion and bone black. The greens are made with smalt and ocher, azurite and malachite, punctually with bone black and vermilion. In the other paintings of this altarpiece, studied by microchemical analysis and optical microscopy, is possible to find little significant variations of the pictorial layers resuming to the following results: in white color lead white and chalk, in the yellow color the yellow ochre as main pigment, in the green color, the main pigments verdigris and malachite, in the blue color azurite, smalt and verdigris, in the brown color ochre, in the red color red ochre and vermilion and in the black color, bone black $[18,19]$. The binder of the chromatic layers is mostly oil and occasionally animal glue, detected by the $\mu$-FTIR technique, for example in the white and in the blue colors [18].

The material analysis of the pictorial strata of the painting Our Lady of the Assumption (A2) was carried out during its restoration [43]. The pictorial construction is made in one or two chromatic layers, usually applied with mixtures of pigments. In the binders the oil is highlighted, a)

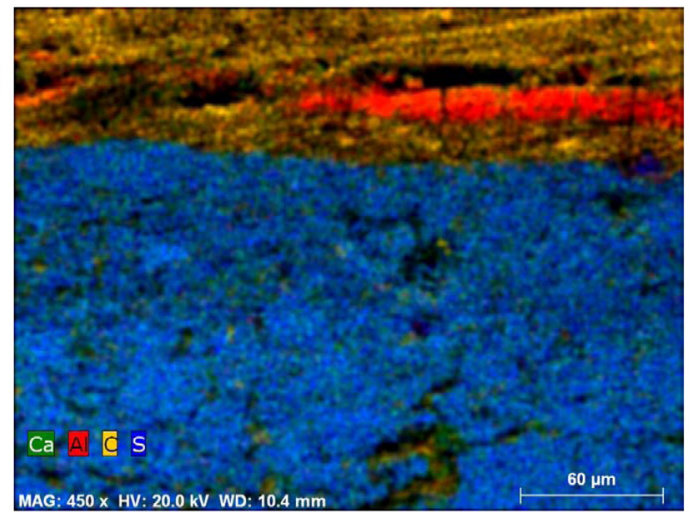

b)

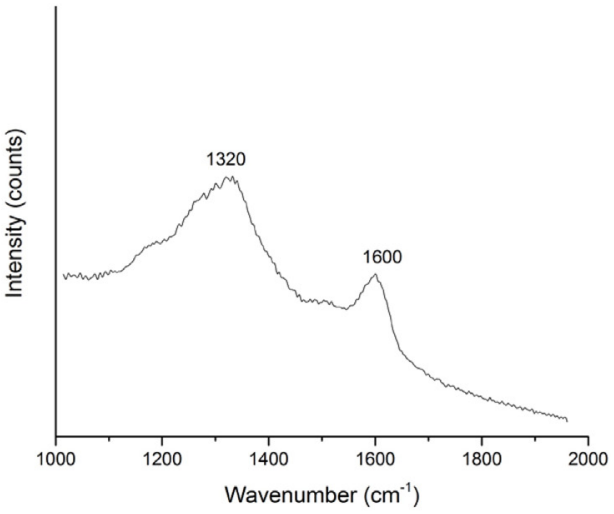

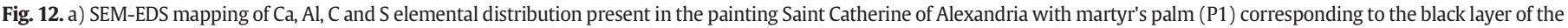

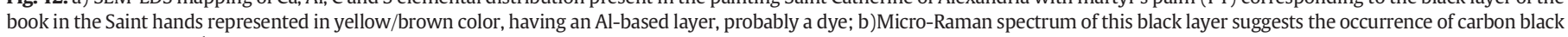
at 1320 and $1601 \mathrm{~cm}^{-1}$. 
with the exception of the yellow halo area, being yellow egg. Lead-tin yellow color stands out in the yellow; in blue color, azurite; in white color, lead white and chalk; in brown color, ochre; in black color, carbon black; in the green color, malachite, copper resinate and verdigris, and in red color madder and vermilion. The hair consists of a mixture of ochre, vermilion and carbon black; the light blue mantles present a mixture of chalk, azurite and carbon black, being the dark blues constituted only by the last two pigments. The green mantles have a mixture of verdigris and lead white and the red mantles have madder and vermilion; both the white mantles and the clouds are composed of lead white and azurite, the red background being a mixture of madder and ochre and the yellow rays consisting of lead-tin yellow and chalk. The carnations were executed with the mixture of vermilion and lead white, sometimes with madder [43].

The study on the constituent materials of the painting Testimony of Saint John the Baptist with the priests and Levites of Jerusalem (A4) was intended to aid in the cleaning of a deep repainting for which it only contemplated some colors [13]. The sky consists of lead white and azurite and the red of the priest's mantle is composed of a layer of vermilion underlying a red dye, probably madder, and over a lead white layer, a possible priming [44].

\section{Conclusions}

The results obtained by the different analytical techniques allowed studying Goa Cathedral former altarpiece. The correspondence of these data with other groups of paintings assigned to Garcia Fernandes workshop suggests a similarity of materials and techniques, showing a fidelity to the working processes:

-The use of northern Europe Baltic oak as support of the paintings, uncommon in Goan painting but of frequent use in Portugal, and most particularly in Lisbon workshop in addition to a similar panel construction technique;

-The employment of gesso grosso (greater amount of anhydrite than gypsum) as the major component of the ground layers, incorporating also the gesso mate technique (more gypsum than anhydrite), as described for gilded altarpieces in Portuguese treatises, possibly for a better conservation of the paintings in Goa climate; the occurrence of Ba in the grains of Sr, probably of celestite, inserted in the matrix of calcium sulfate, appearing in the painting Saint Catherine of Alexandria with martyr's palm (P1) of Goa Cathedral former altarpiece an also in the paintings Testimony of St. John the Baptist with the priests and Levites of Jerusalem (A4) and Adoration of the Magi and in the central predella of the altarpiece of Bartolomeu Joanes (A3) from Lisbon Cathedral, suggests a similar provenance of calcium sulfate material;

-The use of a comparable palette concerning the same main-pigments for the construction of similar colors and mixtures: for the yellow color lead-tin yellow and ochre; for the blue color azurite; for the white color, lead white; red ochre and carbon black in the brown color; in the black color carbon black; azurite, lead white, yellow ocher, vermilion and a green pigment, possibly verdigris, in the green color; vermilion, red ocher and a red dye for the red color; vermilion, ochre and red dye for the carnation color;

-The use of lead white for the construction of clear tones and carbon black for the shadow tones, as main pigments;

-The use of similar stratigraphic technique concerning the employment of partial priming layers in specific colors, such as red and brown colors;

-A comparable underdrawing with similar employment of a carbon black pigment by wet brush, defining a vigorous drawing with marked shadow and light areas.

By comparing the results obtained by the different techniques, mainly focusing in the ground layers differences and pigment mixtures, it was possible to find resemblances with the paintings previously studied assigned to Garcia Fernandes. Similar techniques and materials were found in the study of Goa Cathedral former altarpiece, reinforcing the hypothesis of being a Portuguese altarpiece.

In conclusion, it was possible, with the study of the materials and the painting technique, to emphasize the origin of Goa Cathedral former altarpiece as Portuguese work of art, as stated before by art historians.

\section{ACKNOWLEDGMENTS}

The authors acknowledge to Most Rev. Filipe Neri Ferrão, Archbishop of Goa and Daman, to Fr Joaquim Loiola Pereira and to Fr. Alfred Vas for allowing this study. Also wish to acknowledge to Fundação Calouste Gulbenkian for financial support through the project "De artibus in auream Goa" and Fundação para a Ciência e Tecnologia for financial support (Post-doc grant SFRH/BPD/103315/2014) through program QRENPOPH-typology 4.1., co-participated by the Social European Fund (FSE) and MCTES National Fund. Also acknowledge Natasha Fernandes and Museum of Christian art (MOCA), Mónica Reis and José Pestana, for the assistance in the project and Maria José Oliveira for the assistance in the $\mu$-XRD. This work was supported by the research center grant no. UID/FIS/04559/2013 to LIBPhys-UNL, from the FCT/MCTES/PIDDAC and research center grant no. UID/Multi/04449/2013 to Hercules Laboratory.

\section{References}

[1] M. Malkiel-Jirmounsky, Pintura à sombra dos mosteiros, a pintura religiosa portuguesa nos séculos XV e XVI, Atica, Lisboa, 1957.

[2] F.A. Baptista Pereira, A pintura num período de transição, in: D. Markl (Ed.), História da arte em Portugal-O Renascimento, Alfa, Lisboa 1986, pp. 83-155.

[3] D. Rodrigues, A pintura num século de excepção, 1450-1550, Fubu editores, Sa, Lisboa, 2009.

[4] J.O. Caetano, Garcia Fernandes, in: Francisco Faria Paulino (Ed.), Grão Vasco e a pintura europeia do Renascimento : Galeria de Pintura do Rei D. Luís, 17 de Março a 10 de Junho de 1992, Comissão Nacional para as Comemorações dos Descobrimentos Portugueses, Secretaria de Estado da Cultura, Instituto Português do Património Cultural \& Instituto Português de Museus, Portugal 1992, pp. 357-360.

[5] L. Reis Santos, Garcia Fernandes, Artis, Lisboa, 1957.

[6] L. Reis Santos, Escritura de 1514 referente a cinco pintores portugueses, in: E.D. Autor (Ed.), Estudos de pintura antiga, Gráfica Santelmo, Lisboa 1943, pp. 251-256.

[7] J.O. Caetano, Garcia Fernandes, in: A.C. Gouveia, F.A.B. Pereira (Eds.),Francisco Henriques:um pintor em Évora no tempo de D. Manuel I, Comissão Nacional para as Comemorações dos Descobrimentos Portugueses 1997, pp. 212-215.

[8] J.A.S. Carvalho, Garcia Fernandes, Figura E. luz Cores, Pintura portuguesa do século XVI na colecção do Museu Nacional de Soares dos Reis, Museu Nacional de Soares dos Reis, Porto, 200469.

[9] M.E. Reis, De Portugal para a Índia. O Percurso da Arte Retabular na antiga Província do Norte e em Goa, Inventário Artístico do Taluka de Tiswadi, Universidade do Algarve, 2016.

[10] A.D. Lacerda, Notícia acerca de um quadro primitivo de Sardoura, Prisma, Vol. 2, Novembro de 1936, pp. 111-128.

[11] D. Markl, Os ciclos:das oficinas à iconografia, in: P. Pereira (Ed.), História da Arte Portuguesa, Do “Modo" Gótico ao Maneirismo, Círculo de Leitores e Autores, Lisboa 1995, p. 537.

[12] M. Batoréo, V. Serrão, O Retábulo de São Bartolomeu da Sé de Lisboa. Garcia Fernandes numa obra de Parceria, in: J.O. Caetano (Ed.), Garcia Fernandes-um pintor do renascimento. Eleitor de Misericórdia de Lisboa, Santa Casa da Misericórdia, Museu de São Roque, Lisboa 1998, pp. 87-103.

[13] D. Delgado, in: P.D.D.R.N. (Ed.), Relatório de restauro no 9/98 da pintura "S. João Baptista e o Sumo Pontífice" do Museu Nacional de Arte Antiga/Museu Nacional de Soares dos Reis, Instituto de José de Figueiredo, Lisboa 2001, p. 16 9/98. (Outubro de).

[14] J.A.S. Carvalho, Oficinas de Lisboa, Garcia Fernandes, Figura E. Luz Cores, Pintura portuguesa do século XVI na colecção do Museu Nacional de Soares dos Reis, Museu Nacional de Soares dos Reis, Porto, 2004 28-35.

[15] Processo de restauro no 67/79 da pintura "Nossa Senhora da Assunção”, Igreja Matriz de Santa Maria de Sardoura, Instituto José de Figueiredo, Lisboa, 1979.

[16] L.M. Alves, Relatório no 18-86, análise material da pintura "Nossa Senhora da Assunção", Igreja de Sardoura, Processo de restauro n 67/79, Instituto de José de Figueiredo, Laboratório Central do Instituto Português do Património Cultural, Lisboa, 198613.

[17] T.H.D. Mello, E. Matos, I. Ribeiro, Na. Senhora da Assunção, in: J.O. Caetano (Ed.) Igreja de Sardoura. Estudo técnico-científico da pintura e sua conservação. Suporte, Eleitor de Misericórdia de Lisboa, Santa Casa da Misericórdia, Museu de São Roque, Lisboa 1998, pp. 105-107 (Garcia Fernandes - um pintor do renascimento).

[18] P.D.S.L. Alves, Aplicação da Microscopia de Infravermelho com Transformada de Fourrier à caracterização de aglutinantes em pintura portuguesa do séc. XVI-Garcia Fernandes, Departamento de Química e Bioquímica, Faculdade de Ciências da Universidade de Lisboa, Lisboa 2001, p. 102 (Dezembro de). 
[19] I. Ribeiro, Processos n 7-00 e 39-00, análise material do retábulo de S. Bartolomeu da Sé de Lisboa, Departamento de Estudos de Materiais - Instituto Português de Conservação e Restauro, Lisboa, 2000.

[20] P. Klein, Report on the Dendrochronological Analysis of the Panel "Christ and the Apostles" (Garcia Fernandes), Universitat Hamburg, Hamburg, 2001.

[21] L. Esteves, A dendrocronologia aplicada às obras de arte, Agosto de 200320

[22] Processo de restauro n 9/98 da pintura "S. João Baptista e o Sumo Pontífice" do Museu Nacional de Arte Antiga/Museu Nacional de Soares dos Reis. , Instituto José de Figueiredo, Lisboa, 1998.

[23] P. Klein, Report on the dendrochronological analysis of the panel "S. João Baptista e o Sumo Pontífice", Universitat Hamburg, Hamburg, 20001.

[24] M.-J. Benquerença, N. Mendes, E. Castellucci, V.M.F. Gaspar, F. Gil, Micro-Raman spectroscopy analysis of 16th century Portuguese Ferreirim masters oil paintings, J. Raman Spectrosc. 40 (2009) 2135-2143.

[25] V.M.F. Gaspar, A pintura quinhentista do convento de Santo António de Ferreirim, parceria dos mestres Cristóvão de Figueiredo, Garcia Fernandes e Gregório Lopes, Direcção Regional da cultura do Norte/Vale do Varosa, Lamego, 2015.

26] V. Antunes, A. Candeias, J. Mirão, M.L. Carvalho, V. Serrão, C.B. Dias, A. Manhita, M.E. Reis, M. Manso, Preserving European paintings in Asian environment. The case of Goa cathedral former altarpiece, 5, Structural Integrity Procedia Elsevier, 2017 1078-1085.

27] V. Antunes, A Candeias, M.L Carvalho, C. Dias, MJ. Francisco, S. Costa, A. Lauw, V. Serrão, M. Manso, Uncover the mantle: rediscovering Gregório Lopes palette and technique with a study on the painting "Mater Misericordiae”, Appl. Phys. 122 (2016) 1-14.

[28] M. Guerra, S. Pessanha, M. Manso, S. Longelin, M.L. Carvalho, Theoretical and experimental study on the angular dependence of scattering processes in XRF systems, XRay Spectrom. 42 (2013) 402-407.

29] M. Guerra, M. Manso, S. Longelin, S. Pessanha, M.L Carvalho, Performance of three different Si X-ray detectors for portable XRF spectrometers in cultural heritage applications, J. Instrum. 7 (2012) 1-9 (14th International Workshop on Radiation Imaging Detectors (IWORID2012))

[30] V. Antunes, A. Candeias, M.J. Oliveira, M. Lorena, A.I. Seruya, M.L. Carvalho, M. Gil, J. Mirão, J. Coroado, V. Gomes, V. Serrão, Calcium sulphate fillers and binders in Portuguese 15th and 16th centuries: ground layers from a family painting workshop study by multianalytical spectroscopic techniques, Microchem. J. 125 (2016) 290-298.

[31] V. Antunes, A. Candeias, M.L. Carvalho, M.J. Oliveira, M. Manso, A.I. Seruya, J Coroado, L. Dias, J. Mirão, S. Longelin, V. Serrão, Gregório Lopes painting workshop: characterization by X-ray based techniques-analysis by EDXRF, $\mu$-XRD and SEMEDS, JINST, J. Instrum. 9 (2014) (1748-0221).

[32] I.M. Bell, R.J.H. Clark, P.J. Gibbs, Raman spectroscopic library of natural and synthetic pigments (pre- $\approx 1850$ AD), Spectrochim. Acta A Mol. Biomol. Spectrosc. 53 (1997) 2159-2179.

[33] L. Burgio, R.J.H. Clark, Library of FT-Raman spectra of pigments, minerals, pigment media and varnishes, and supplement to existing library of Raman spectra of pigments with visible excitation, Spectrochim. Acta A Mol. Biomol. Spectrosc. 57 (2001) 1491-1521.

[34] R.T. Downs, The RRUFF Project: an integrated study of the chemistry, crystallography, Raman and infrared spectroscopy of minerals, Program and Abstracts of the 19th General Meeting of the International Mineralogical Association in Kobe, Japan, Vol. 003-13, 2006, p. 117.

[35] V. Antunes, A. Candeias, M.L. Carvalho, M.J. Oliveira, A.I. Seruya, J. Coroado, L. Dias, J. Mirão, S. Longelin, V. Serrão, Characterization of gypsum and anhydrite ground layers in 15th and 16th centuries Portuguese paintings by Raman spectroscopy and other techniques, J. Raman Spectrosc. 45 (2014) 1026-1033.

[36] T. Costa, Pesquisa sobre sistemas de reforço e assemblagem em suportes de pintura, Conservação e restauro: cadernos (2007) 48-54

[37] X.M. Martins, Portuguese Shipping and Shipbuilding in Goa 1510-1780, Goa University, 1994

[38] A. Lauw, L. Esteves, M. Teles, Pinturas do século XV e XVI uma abordagem dendrocronológica, in: V. Serrão, V. Antunes, A.I. Seruya (Eds.), Colóquio Internacional sobre As Preparações na Pintura Portuguesa dos Séculos XV e XVI, Auditório do Museu Nacional de Arte Antiga, 28 e 29 de Junho de 2013, Faculdade de Letras da Universidade de Lisboa, Lisboa 2013, pp. 279-288.

[39] V. Antunes, Técnicas e materiais de preparação na pintura portuguesa dos séculos XV e XVI, Instituto de História da Arte da Universidade de Lisboa, Faculdade de Letras da Universidade de Lisboa, Lisboa, 2014.

[40] M.I.F.P. Cardoso, Gesso Layers on Portuguese Baroque Altarpieces: Materials, Practices and Durability, Institute of Archaeology, University College London, London, 2010783.

[41] P. Nunes, in: L Ventura (Ed.). Arte da Pintura, Symmetria e Perspectiva, fac-simile da edição de 1615 com um estudo introdutório de Leontina Ventura, Editorial Paisagem, Porto, 1982.

[42] J. Coroado, V. Antunes, V. Serrão, M.J. Oliveira, A. Candeias, J. Mirão, M.L. Carvalho, L. Dias, A.I. Seruya, Presença de Celestite em Retábulos Portugueses, in: V. Serrão, V. Antunes, A.I. Seruya (Eds.), Colóquio Internacional sobre As Preparações na Pintura Portuguesa dos Séculos XV e XVI, Auditório do Museu Nacional de Arte Antiga, 28 e 29 de Junho de 2013, Faculdade de Letras da Universidade de Lisboa, Lisboa 2013. pp. 75-84.

[43] T.H.D. Mello, E. Matos, I. Ribeiro, "Na. Senhora da Assunção" - Igreja de Sardoura. Estudo técnico - científico da pintura e sua conservação, in: J.O. Caetano (Ed.), Estudo Material, Garcia Fernandes- um pintor do renascimento. Eleitor de Misericórdia de Lisboa, Santa Casa da Misericórdia, Museu de São Roque, Lisboa 1998, pp. 108-111.

[44] A.M.E. Carmo, I. Ribeiro, M.D.C. Serrano, in: Processo de restauro no 9/98 (Ed.) Relatório no 44-00, análise material da pintura "S. João Baptista e o Sumo Pontífice" do Museu Nacional de Arte Antiga/Museu Nacional de Soares dos Reis, Instituto dos Museus e da Conservação, Lisboa 2001, p. 7.

[45] A.J. Cruz, Pigmentos e corantes das obras de arte em Portugal, no início do século XVII, segundo o tratado de pintura de Filipe Nunes, 6, Conservar Património, 2007 39-51.

[46] J. Boon, F. Hoogland, K. Keune, Chemical processes in aged oil paints affecting metal soap migration and aggregation, in: H.M. Parkin (Ed.), AIC Paintings Specialty Group Postprints: Papers Pres. at the 34th Annual Meeting of the AIC of Historic \& Artistic Works Providence, AIC PSG Postprints, Washington 2007, pp. 16-23.

[47] V. Antunes, A. Candeias, M.L. Carvalho, C.B. Dias, A. Manhita, M.J. Francisco, A. Lauw, M. Manso, Analytical characterization of Jorge Afonso palette and painting techniques, the great master of Lisbon painting workshop, Spectrochim. Acta A Mol. Biomol. Spectrosc. 193 (2017) 264-275, https://doi.org/10.1016/j.saa.2017.12.027. 